\title{
CAMA
}

Centre for Applied Macroeconomic Analysis

\section{Australian Prudential Regulation Before and After the Global Financial Crisis}

\section{CAMA Working Paper 49/2016 August 2016}

\section{Peter Docherty}

Economics Group, UTS Business School, University of Technology Sydney

\section{Ron Bird}

Economics Group, UTS Business School, University of Technology Sydney

Paul Woolley Centre for the Study of Capital Market Dysfunctionality, University of Technology Sydney

\section{Timo Henckel}

Centre for Applied Macroeconomic Analysis, ANU

\section{Gordon Menzies}

Economics Group, UTS Business School, University of Technology Sydney

Paul Woolley Centre for the Study of Capital Market Dysfunctionality, University of Technology Sydney and

Centre for Applied Macroeconomic Analysis, ANU 


\section{Abstract}

This paper reviews the nature of Australian bank prudential regulation before and after the Global Financial Crisis (GFC). It provides a detailed conceptual framework for understanding the functions of banks and deposit-takers, the theory of what can go wrong with the operation of these institutions, and the logic of prudential regulation. It traces developments in Australian prudential regulation from the introduction of the formal capital-based framework in the 1980s to the implementation of the Basel III regime after the GFC. The paper concludes that i) the introduction of the Financial Claims Scheme was a clear and welcome change compared with pre-GFC arrangements; ii) the introduction of the Basel III liquidity regime constituted a more fundamental modification, best characterised as a significant refinement to the riskbased calculation of capital than as a fundamental change to regulatory philosophy; iii) the Australian Prudential Regulation Authority (APRA) had been practising macroprudential regulation well before the GFC even though Australia's adoption of Basel III's macroprudential apparatus appears on the surface to constitute a genuine innovation in prudential regulation; and iv) the importance of financial stability as a policy objective and the nature of macroprudential regulation raise questions about the wisdom of having split monetary policy and prudential regulation functions in 1998, and a revisit of this question and a reassessment of institutional structures are called for.

\section{Keywords}

banking, financial crises, prudential regulation, macroprudential supervision

\section{JEL Classification}

G21, G28

\section{Address for correspondence:}

(E) cama.admin@anu.edu.au

\section{ISSN 2206-0332}

The Centre for Applied Macroeconomic Analysis in the Crawford School of Public Policy has been established to build strong links between professional macroeconomists. It provides a forum for quality macroeconomic research and discussion of policy issues between academia, government and the private sector.

The Crawford School of Public Policy is the Australian National University's public policy school, serving and influencing Australia, Asia and the Pacific through advanced policy research, graduate and executive education, and policy impact. 


\title{
Australian Prudential Regulation Before and After the Global Financial Crisis
}

\author{
Peter Docherty ${ }^{*}$, Ron Bird ${ }^{*}, \dagger$, Timo Henckel ${ }^{*}$ \\ and Gordon Menzies",
}

\begin{abstract}
This paper reviews the nature of Australian bank prudential regulation before and after the Global Financial Crisis (GFC). It provides a detailed conceptual framework for understanding the functions of banks and deposit-takers, the theory of what can go wrong with the operation of these institutions, and the logic of prudential regulation. It traces developments in Australian prudential regulation from the introduction of the formal capital-based framework in the 1980s to the implementation of the Basel III regime after the GFC. The paper concludes that i) the introduction of the Financial Claims Scheme was a clear and welcome change compared with pre-GFC arrangements; ii) the introduction of the Basel III liquidity regime constituted a more fundamental modification, best characterised as a significant refinement to the risk-based calculation of capital than as a fundamental change to regulatory philosophy; iii) the Australian Prudential Regulation Authority (APRA) had been practising macroprudential regulation well before the GFC even though Australia's adoption of Basel III's macroprudential apparatus appears on the surface to constitute a genuine innovation in prudential regulation; and iv) the importance of financial stability as a policy objective and the nature of macroprudential regulation raise questions about the wisdom of having split monetary policy and prudential regulation functions in 1998, and a revisit of this question and a reassessment of institutional structures are called for.
\end{abstract}

JEL Classification Numbers: G21, G28.

Keywords: banking, financial crises, prudential regulation, macroprudential supervision.

*Economics Group, UTS Business School, University of Technology Sydney; $\uparrow$ Paul Woolley Centre for the Study of Capital Market Dysfunctionality, University of Technology Sydney; $\$$ Centre for Applied Macroeconomic Analysis, Australian National University.

Thanks to the Centre for International Finance and Regulation for funding support. Thanks to three anonymous referees and to Stephen Grenville and Chris Terry for comments, discussion and suggestions. Any remaining errors are the authors' responsibility. Correspondence to Peter Docherty, Economics Group, UTS Business School, University of Technology, Sydney, PO Box 123 Broadway, NSW, 2007, Australia. Ph. 612 9514-7780; Fax 612 9514-7777; E-mail: peter.docherty@uts.edu.au. 


\section{Introduction}

The Global Financial Crisis of 2007-2009 was characterised by the failure of large financial institutions, significant contagion between institutions, and the propagation of negative effects from the financial system to the real economy, especially in the United States. Prevention and amelioration of such effects is supposed to be one of the central objectives of well-designed prudential regulation, and so an important consequence of the crisis has been a re-evaluation of regulatory frameworks around the world. While Australia was relatively unscathed by the crisis (see Bajada \& Trayler 2010; and Davis 2011) such a re-evaluation is also worth undertaking here to ensure that the Australian system sufficiently discourages the kinds of behaviour that led to the crisis and that financial institutions are sufficiently protected from negative financial events associated with such crises.

Two and a half decades ago, Hogan \& Sharpe (1990) considered the nature of changes to Australia's system of prudential supervision that had occurred across the 1980s. This involved a move from what they characterised as an informal system of supervision to a more formal one built around the first Basel framework. ${ }^{1}$ Such a move was necessitated by the deregulation of Australia's financial system as recommended by the Campbell Committee (Australian Financial System Inquiry 1981) and focused on market-related tools rather than the complex system of controls that had been in place since passage of the Banking Act in 1945. But Hogan \& Sharpe pointed to potential gaps in the structure of this system associated with vagueness in the Banking Act's concept of depositor protection that they thought could lead to financial instability. They recommended the introduction of deposit insurance to plug this gap as well as a re-orientation of thinking about the logic of prudential regulation itself.

Ten years later, Thomson \& Abbott (2000) reviewed the development of prudential regulation in Australia, arguing that this development had been ad hoc and reactionary, and suggesting that the Wallis Committee's recommendation of a move to a functionallybased system would significantly enhance its effectiveness. Their criteria for effectiveness included the idea of competitive neutrality as much as the objective of financial stability and central to the measures they thought would enhance effectiveness was the separation of central banking from prudential supervision that the Wallis Committee had also recommended.

\footnotetext{
${ }^{1}$ This framework, known now as Basel I, was promulgated by the Bank for International Settlements in the mid-1980s.
} 
The objective of this paper is to revisit the issues considered by Hogan \& Sharpe (1990) and Thomson \& Abbot (2000) in the light of the Global Financial Crisis but more specifically to compare the nature of prudential bank regulation before and after the crisis. The paper argues that the clarification of the extent of depositor protection afforded by the Financial Claims Scheme introduced after the Global Crisis is to be welcomed as are changes to core capital and liquidity regulations. The introduction of Basel III's macroprudential tools is also assessed as a positive development. The paper demonstrates, however, that these new tools simply make explicit a feature of the Australian system that has always been present: that monetary policy and prudential regulation are closely connected. The paper also argues that explicit consideration of macroprudential tools raises questions about the institutional structure surrounding prudential regulation and that the separation of monetary policy and prudential regulation engineered in 1998 should be reconsidered.

The paper is structured as follows. Section 2 reviews the functions of banks and deposit-takers and Section 3 reviews what can go wrong with the operation of these institutions and the logic of the regulation imposed upon them to prevent or reduce the likelihood of these problems emerging. Section 4 examines the transition from what Hogan \& Sharpe called Australia's informal system of prudential regulation to the formal capital-based system that occurred in the 1980s. Section 5 considers developments subsequent to this fundamental shift of the 1980s, principally the separation of central banking from prudential supervision recommended by the Wallis Committee. Section 6 looks at the Australian response to the development of the Basel II framework. All of this provides important background to the state of prudential regulation in Australia when the Global Financial Crisis hit in 2007. Section 7 reviews the key features of the crisis itself. Section 8 examines prudential developments internationally after the crisis and Section 9 looks at these developments in the Australian context. Section 10 then evaluates the changes to depositor protection arrangements and liquidity regulation in Australia after the crisis and Section 11 does the same thing for capital and macroprudential regulation. Section 12 considers the issue of macroprudential regulation in historical perspective, and Section 13 discusses the institutional structure surrounding Australian prudential regulation. Finally, Section 14 summarises and concludes. 


\section{The Functions of Banks and Deposit-takers}

The theory of financial intermediation as it has evolved over the last 30 or so years may be summarised in terms of three broad functions performed by a developed financial system: the provision of payments services such as clearing and payments settlement; the movement of surplus funds from those who save them to those who use them for financing real investment opportunities; ${ }^{2}$ and the reduction of various risks which arise on account of the first two functions (see Bhattacharya, Boot \& Thakor 1998, p.747). ${ }^{3}$ The more efficiently these functions are performed, the higher the level of economic activity, the faster the rate of growth in this activity and the better living standards in any given economy. Conversely, when these functions are disrupted, fluctuations may occur in the level and growth rate of economic activity with associated negative implications for employment and welfare.

Banks perform all three functions, and all three functions are important for understanding the structure of prudential regulation. A series of studies including Hogan \& Sharpe (1990), Chant (1992), Bhattacharya \& Thakor (1993), Bhattacharya, Boot \& Thakor (1998) \& Mishkin (2001) have shown, however, that the financing function has been the subject of the most extensive analysis over the last thirty years, and at the centre of this analysis are the concepts of asymmetric information and principal-agent problems. According to the concept of asymmetric information, different parties to economic and financial transactions have different access to information about the circumstances surrounding these transactions. For example, a potential borrower knows better than a potential lender how he will use the proceeds of a loan and how much effort he will put into ensuring the success of the project the loan is being sought to finance. This information is likely to have an important bearing on whether the loan is made and the asymmetry in its availability is a potential barrier to the transaction's completion.

The existence and structure of intermediaries such as banks may be seen as the solution to a sequence of information problems which arise in the financing process. This is best

\footnotetext{
${ }^{2}$ An alternative way to conceive of this financing function is that banks endogenously create deposits as a by-product of lending decisions, and the volume of saving then rises as the multiplied investment which bank lending finances, expands national income. This additional saving expands household portfolios and some of this expansion will be held in the form of increased bank deposits. In addition, increased bank deposits will be required to facilitate a larger volume of transactions associated with the higher level of national income. Any discrepancy between the resulting increased demand for bank deposits and the initial increased supply of bank deposits created as the by-product of bank lending will show up in wholesale liquidity markets and necessitate market operations by the central bank to stabilise short-term interest rates given an inflation targeting policy regime. See Lavoie (1999) and Docherty (2005, pp.207-254) for a more detailed discussion of this perspective.

${ }^{3}$ Merton (1995), Hogan \& Sharpe (1997a), and Hunt \& Terry (2005) all identify more than three functions.
} 
seen by first considering the financing process without the involvement of intermediaries. ${ }^{4}$ Without intermediaries, funds may flow from savers to investors if savers simply purchase financial securities issued by borrowers in markets. Different markets specialise in the trading of securities with particular risk and repayment-timing characteristics so that savers should be able to find securities with the characteristics that suit their preferences. The markets for stocks, bonds and short-term notes are all examples of this kind of financing. But accurate information about the financial condition of the borrower, the use to which the funds will be put and the borrower's reliability in terms of repayment is crucial for the effective operation of these markets, and such information is costly to obtain.

If intermediaries become involved in the process, Leyland \& Pyle (1977) show that the cost to each saver of obtaining information about good investment opportunities can be reduced. Rather than each saver separately searching for good investments themselves, the intermediary may conduct a single search and then offer each saver a share in the investment opportunity. The cost of searching is thus shared between all savers rather than paid individually by each one.

But this solution to the problem of costly information gives rise to a second problem which Mishkin (2001, p.3) calls the free-rider problem and Chant (1992) calls the appropriability problem. Having obtained information about good investment opportunities, if the intermediary simply reveals this information to potential savers, other savers will have an incentive to free-ride on this information, observing the behaviour of those who pay for it and purchasing the same securities. Given this possibility, no saver will in fact be prepared to pay for the information since it can be obtained simply by waiting. In turn, no intermediary will be prepared to do the searching which generates the information because they will not be able to recover the associated costs. The opportunity to reduce search costs in the way described above will thus be lost unless a solution can be found to this free-rider or appropriability problem.

The solution to this second problem lies in a central characteristic of intermediary or indirect finance. Rather than simply providing the information to savers, the intermediary takes the investment into its own portfolio and offers savers shares in this portfolio in the form of deposits. In this way it does not need to disclose the collected information, it can

\footnotetext{
${ }^{4}$ So-called direct finance operates between ultimate borrower and ultimate lender and is exemplified by bonds and their trading in bond markets. Indirect finance, on the other hand, involves the facilitation of an intermediary such as a bank which holds separate obligations with ultimate borrower and lender, and thus interposes its own balance sheet between these other counterparties. See Mishkin (2013, p.68).
} 
recover costs by paying a lower interest rate on deposits than it earns on loans in the portfolio, and economies of scale from sharing search costs are exploited.

Unfortunately a third information problem emerges from this solution to the free-rider problem. Information between intermediary and bank is now asymmetric. The intermediary knows more about the loans in the portfolio than do prospective depositors who are thus obliged to undertake some verification of the information possessed by the intermediary if they are to protect their savings, and this is, of course, a costly exercise. However, if verification costs depend on the degree of accuracy, if the intermediary finances part of its portfolio with its own funds, and if it subordinates its claim over the portfolio to that of depositors, verification costs per depositor will be lower than they would be if depositors had to verify without the involvement of an intermediary. This happens because depositors need only verify the quality of the portfolio to the extent that it is funded by deposits which is less than the whole value of the portfolio on account of the capital contributed by the intermediary itself. The solution to this third problem thus explains why capital is an important dimension of the structure of indirect finance through intermediaries.

Reduction of search and verification costs, which Chant (1992) groups under the label of identification costs, explains some of the key features of intermediaries. These costs arise in order to reduce the problem of adverse selection which asymmetric information causes and which was first identified by Akerlof (1970) who showed that the asymmetry increases the probability of encountering a poor quality product; in this context a poor quality loan or a bank that holds poor quality loans in its portfolio. However reducing identification costs is not the only explanation for intermediaries and their characteristics. Reducing the costs of monitoring the use of funds once loans have been made and of enforcing loan contracts to ensure eventual repayment also helps to explain the existence and features of intermediaries. Mishkin (2001, pp.2-3) argues that these costs arise in order to reduce the problem of moral hazard, also created by asymmetric information. This occurs where the behaviour a contractual counterparty changes their behaviour in a way that reduces the probability of the loan being repaid. The involvement of an intermediary can also be shown to reduce these costs.

If monitoring and enforcement costs rise less than proportionately with the value of the loan being monitored, and if the amount of money required by a borrower is greater than the funds available from any individual saver, the cost per borrower of undertaking these activities will be lower under intermediation than if savers undertake them individually in 
securities markets. It will be cheaper to monitor one big loan than a series of smaller ones from individual savers. As always, however, a new problem emerges if savers entrust monitoring and enforcement to an intermediary. Jensen \& Meckling (1976) refer to this kind of problem as a principal-agent problem because the consequences of failing to monitor and enforce properly are borne by the depositor (the principal), while the monitoring and enforcement carried out by the intermediary (the agent). The intermediary thus has an incentive, under certain conditions, to shirk on their monitoring and enforcing responsibilities because this will allow them to collect their fee but to incur fewer costs. The hope is that problems will not emerge with loans due to the lack of monitoring and enforcement and that the higher profits may be retained. However, if the worst case does eventuate and loans are not repaid, the cost of this will be borne by the depositor rather than the intermediary. Under these circumstances depositors will be reluctant to delegate the monitoring and enforcing task to the intermediary unless this additional problem can be solved.

A solution to this principal-agent problem is provided once again by intermediary characteristics. Diamond (1984) shows that if the nominal value of shares in the intermediary's loan portfolio offered to depositors is fixed, and if the intermediary finances part of the portfolio from its own capital, subordinating this claim to that of depositors, the principal-agent problem is resolved. Under this arrangement, the return to the intermediary is dependent on proper monitoring and enforcing. If borrowers fail to repay, depositors have a fixed nominal claim over the portfolio which must be paid before the intermediary receives any return. It is thus important for the intermediary to ensure that loans are repaid in full if they are to earn their expected rate of return. It therefore has an incentive to correctly monitor and enforce loan repayment which serves the interest of depositors as well as that of the intermediary itself.

Fixed nominal claims issued by intermediaries may be contrasted with claims against asset portfolios issued by intermediaries such as mutual funds. With mutual funds, the value of a claim or share in the fund is understood to fluctuate with the market value of the underlying asset portfolio. If the value of this portfolio falls, so does the value of a claim and vice versa. This feature of intermediary or bank liabilities is often argued to provide an important safe haven for unsophisticated savers who want a relatively riskless place to store their savings.

Together with the reduction of identification costs, the reduction of monitoring and enforcement costs provides a strong explanation for the existence and characteristics of 
financial intermediaries such as banks. Additional insights into the contribution made by intermediaries to the resolution of information and principal-agent problems which affect the financing function of the financial system, and which build upon these basic ideas have been offered by a range of theorists. Fama (1985), for example, argues that the access banks have to information on customers' transactions account histories further reduces the cost of identifying good loan prospects. A bank can see that a potential borrower has maintained their transaction account is an orderly fashion over a period of time and is thus able to manage their financial and business affairs competently. This information about the credit worthiness of a potential borrower is available at a lower marginal cost to a bank but would be very expensive for an alternative lender to obtain. Petersen \& Rajan (1994) and Berger \& Udell (1995) argue that identification costs are also reduced by long term bank-borrower relationships since they provide even more information about the ability of borrowers to manage and repay loans. Empirical support for the contribution that intermediaries make in these terms is provided by Lummer \& McConnell (1989) and James (1991) among others.

The role of intermediaries such as banks in providing the second of the three financial system functions outlined at the beginning of this section has thus been the subject of considerable analysis over the last thirty years. This analysis suggests that this financing function could be broken down into four sub-functions involving, firstly, the basic function of transferring resources from savers to investors; secondly, the pooling of small savings to finance larger loans; thirdly, the resolution of adverse selection problems caused by asymmetric information and the reduction of associated information costs; and fourthly, the realignment of incentives misaligned by the principal-agent problem. In fact some economists discuss financial system functions in terms of these four functions plus the payments and risk management functions considered above (see Hogan \& Sharpe 1997a, pp. 20-21). ${ }^{5}$

The contribution made by banks to the performance of financial system functions is the basis for protecting them against serious disruption. The following section outlines the nature of these disruptions and how they provide a justification for prudential regulation.

\section{The Role of Prudential Regulation}

Two ideas are central to understanding how the functions of the financial system in general and intermediaries in particular may be subject to serious disruption. The first

\footnotetext{
${ }^{5}$ See footnote 3 above.
} 
involves adverse shocks to intermediaries in the form of borrower defaults. This may happen due to an economic downturn which affects multiple borrowers or it may happen for reasons specific to a particular intermediary and its borrowers. The second idea is that residual information asymmetry between depositors and intermediaries implies that depositors may be unable to distinguish between healthy and unhealthy intermediaries when some intermediaries are known to be experiencing difficulties. Diamond \& Dybvig (1983) show how under these circumstances bank runs may occur. In addition, Bryant (1980) and Gorton (1988) show that when an adverse shock hits one intermediary, depositors at other intermediaries may not be able to distinguish between institutionspecific and general shocks. In the presence of a sequential service constraint according to which depositors at the front of a withdrawal queue receive their funds in full while those at the back of the queue receive nothing, depositors who misinterpret an institutionspecific shock at another bank for a general shock have an incentive to be first in the queue. Adverse shocks combined with asymmetric information thus have the potential to generate bank runs and contagion of runs from bank to bank.

Shocks which affect multiple borrowers may themselves be understood in two ways. Firstly they may be seen as random changes to income flows occasioned by events such as the effect of poor weather on agricultural output, the effect of storms or earthquakes on productive capacity, or changes to demand patterns such as a decline in foreign spending on domestic exports. Secondly, they may be seen as generated endogenously by dynamics associated with sustained periods of economic growth. Minsky (1964), for example, argues that such periods of sustained growth which increase returns to capital can lead to more optimistic expectations of future returns and increased investment in incomegenerating assets. This is likely to increase the price of such assets. If interest rates are low and the credit supply elastic, these buoyant conditions may provide the occasion for increased speculative activity which leads to further rises in asset prices and upwardly revised price expectations. If the ratio of debt to income flows rises significantly during such periods, debt servicing burdens also increase so that even moderate increases in interest rates are capable of causing greater loan defaults. Such increased interest rates can occur if consumer price inflation emerges in the buoyant conditions and the central bank decides to tighten the policy rate. But downward revisions to asset price expectations can also lead to significant falls in such prices, generating insolvencies for leveraged investors and increased default rates. In the growth phase of such phenomena, Minsky (1964, p.333) argues, there also tends to be a reduction in the ratio of outside liquidity (assets that 
involve little or no dealt risk such as cash, gold and directly held public debt) to income, and that in the default phase, demand for liquidity increases dramatically as a "flight to safety" effect is observed. Kindleberger (2000) and Borio (2005) also examine the potential for similar growth-related credit dynamics to endogenously generate increased defaults. Whichever view is taken of how increased defaults are generated, the occurrence of such defaults in the presence of asymmetric information has the potential to cause bank runs and contagion from bank to bank.

This may cause significant disruption to the financing process as some banks fail with depositors losing funds and surviving banks restricting credit availability. This in turn implies that firms may find it difficult to obtain funding for new investment projects, and economic activity may, therefore, be severely disrupted (Bernanke 1983; Bernanke \& Lown 1991). Hogan \& Sharpe (1997a, p.17) also point to inter-bank exposures via the clearing system as a potential source of contagion.

The consequences from bank failures and contagion are clearly undesirable and should be the object of measures designed to reduce or avoid them. Hogan \& Sharpe (1997a, p.17) identify two broad mechanisms that might achieve this goal. The first is market discipline. In its pure form, this approach argues for an absence of any public assistance to individuals or institutions when negative shocks generate deposit losses or contagion (e.g. see Dowd 1996; and Goodhart 1988). Such a policy, it is argued, gives depositors an incentive to more carefully monitor the riskiness of their bank's loan portfolio and to withdraw deposits from a bank exposed to excessive risk. Banks which experience such withdrawals will be forced to either reduce their risk exposures or offer higher deposit rates to compensate depositors for the additional risk. But higher deposit rates will reduce bank profits and thus bank stock prices, leading to shareholder disciplining of bank management. Managers will thus have an incentive to redress excessive risk exposures, and sufficient scope exists within the market itself to keep risk under control according to this view.

The main problem with this view, however, is that it overlooks the problem of asymmetric information that makes it difficult for depositors to monitor the quality of bank loans. The second mechanism identified by Hogan \& Sharpe then is the extension of some kind of Government Safety Net (GSN) to reduce the impact of deposit losses, either directly or from contagion, and to avoid the real economic consequences that may also be associated with bank runs. This safety net normally takes one of two forms: explicit deposit insurance where deposits are guaranteed up to some ceiling (e.g. $\$ 100,000$ in the 
U.S.) and premia charged to banks for this coverage are paid into a fund from which payments to depositors can be made in the event of bank failure; or a lender of last resort (LLR) facility where loans are provided usually by the central bank either directly to troubled institutions or indirectly to the banking system as a whole (Mishkin 2001, pp.5$6)$.

Once again, however, the solution to one problem can create subsidiary problems in its place. In this case, the provision of a GSN reduces any incentive bank depositors have for monitoring the bank, so that bank managers now have an incentive to take greater risks than was previously the case. Under certain conditions, since the payoffs from good outcomes may involve higher bank profits and executive salaries, whereas the GSN places a floor under payoffs on the downside, the incentives may exist to increase the risk profile of intermediaries and thus the likelihood that the GSN will be needed.

This is essentially the rationale for prudential regulation. Mishkin (2001, p.1) defines such regulation to be "regulation and monitoring of the banking system to ensure its safety and soundness" and its objective is to reduce the problems of moral hazard and adverse selection created by the provision of the GSN. Bhattacharya, Boot \& Thakor (1998, pp.756-760) and Mishkin (2001, pp.8-12) identify a range of forms that prudential regulation of this type can take.

\section{Restrictions on the Composition of Assets}

These restrictions have tended to mandate minimum bank liquidity holdings. As highlighted above, demand for liquidity tends to rise in periods of financial distress since liquid assets avoid the possibility of capital losses from declines in asset prices or credit default and they provide investors with purchasing power to quickly alter the composition of their portfolios in the recovery phase (see Dow 1996). Minsky (1964) argued that the ratio of liquidity to income tends to fall during expansions and hence restrictions on bank asset compositions which require a minimum holding of liquidity relative to liabilities have the potential to moderate this effect, to reduce the amount of risk in the asset portfolio by substituting what tend to be safer, liquid assets for riskier loans, and to engender depositor confidence that a bank has the ability to provide cash for deposits if this is required. This relaxes the sequential service constraint discussed above and makes a bank run less likely. 


\section{Risk-sensitive Deposit Insurance Premia or Capital Requirements}

Under this type of regulatory structure, riskier loans raise the cost to banks of deposit insurance thus reducing profits with the same disciplinary effects on bank management outlined above from higher interest rates. Risk-sensitive capital requirements increase the amount of capital banks must have on their balance sheet as loan risk rises, and since capital is a costly source of funds, bank managers will be circumspect about the amount of risk to which they expose the bank. Both of these regulatory devices thus function as a substitute for market discipline.

\section{Disclosure Requirements}

These attempt to overcome the informational asymmetry between depositor and intermediary which makes monitoring more difficult. Banks may be required to report a range of information to "the market" which depositors may use in deciding where to allocate their deposits. Such measures are designed to enhance market discipline by shifting the monitoring cost from depositors to banks. The major problem with such measures, however, is that disclosure may give depositors the means to exert discipline but in the presence of a GSN they still lack the incentive to perform this function. Some economists argue that such disclosure requirements function best when banks make use of subordinated debt by banks to finance their portfolios. Holders of this debt are not usually covered by deposit insurance but rank behind depositors in the liquidation queue of a failed institution. They are more likely to be institutional investors with the skills necessary to digest complex financial data associated with disclosure requirements.

\section{Bank Chartering}

Determining who is allowed to possess a banking licence is a means of minimising adverse selection. By vetting potential licence holders, regulators may exclude people with poor business experience, a history of filing for bankruptcy or any other characteristics that potentially signal an excessive appetite for risk.

Mishkin (2001) adds to this list the separation of banking from other financial services such as securities trading and underwriting, and restrictions on competition in the banking industry which was the objective of the 1933 Glass-Steagall Act in the United States. The first of these recognises that securities trading and underwriting are significant sources of risk. The second has the effect of substituting monopoly profits for risk-related profits. It is thus not a guarantee that risk will not be pursued by banks granted a licence but there is 
a clear incentive in this direction since the licence is usually at the pleasure of some regulatory body and may have conditions attached.

Bhattacharya, Boot \& Thakor (1998, p.757) identify a combination of partial deposit insurance and market discipline as an additional regulatory approach. This corresponds to Hogan \& Sharpe's (1997, pp.21-25) support for the functional approach to prudential supervision. According to this approach, a GSN of some form is offered only to institutions which deliver transactions deposits, and these institutions are subject to extremely tight asset restrictions, being required to hold as much as $100 \%$ of liabilities in the form of liquid government securities. No other type of deposit has access to the GSN but institutions which offer these deposits are not regulated at all. This type of institution thus faces only market discipline. All of these approaches tend to focus, however, on institution-specific risk and tend not to consider the possibility that the overall effects of bank lending can generate systemic risk over and above that which is institution-specific (Borio 2005, p.94). This as to become an important development in thinking about prudential regulation after the Global Crisis.

Whichever system of prudential regulation is implemented, two further dimensions are required. These are systems for ensuring compliance on the one hand and for managing non-compliance on the other. The most common system for ensuring compliance is a process of bank examination (Mishkin 2001, p.13). This may be conducted on-site by the regulators themselves, or off-site using information supplied by intermediaries and perhaps certified by some third party. Either way, this system also depends on verification of accurate information. Systems for non-compliance have tended to be more controversial. A commonly advocated approach is bank closure (Bhattacharya, Boot \& Thakor 1998, p.758). Under this system a chronically non-compliant institution is closed or taken over by the regulator and one of two procedures followed. Firstly, its assets may be liquidated and the proceeds passed on to depositors or the regulator, depending on the form of the GSN in place. Secondly, the institution may be sold to another institution and its assets and liabilities absorbed into that institution's operations. Some combination of these procedures is also possible.

The major problem with systems of bank closure is identifying at what point an intermediary should be closed versus required to rectify the non-compliance. Boot \& Thakor (1993) point out that regulators may face a moral hazard problem in making this decision as the result of yet another informational asymmetry. This asymmetry arises from the fact that regulators have access to information about the state of an intermediary not 
available in the market place. In addition, there are two costs to closing an institution. One is the administrative cost to taxpayers of the liquidation or management of a commercial takeover. But a second accrues to the regulator itself in the form of perceptions that it has failed to observe and correct the non-compliance at an earlier stage. Since a trade-off exists between these two costs but they accrue to different parties, the regulator may have an incentive to delay a closure in the hope that the intermediary will recover and it will avoid blame for the problems. This regulatory forbearance has the potential to increase losses and tax payer costs and represents an important weakness with systems of prudential regulation.

Actual regulatory systems in countries around the world, including that in Australia, reflect, in various measures, the principles and possibilities identified in the above framework. Thompson (1991a, p.121) argues that such systems be evaluated by the extent to which bank depositors have suffered losses. But this can only represent a limited part of the appropriate evaluation criteria. Attention must also be paid to the rationale underlying the system itself. There is a significant difference between the ex post realisation of risk and the ex ante risk of depositor losses. A system which has to date not suffered significant losses is not necessarily a system which is not at risk. If the above framework summarises our best understanding of the functions of financial intermediaries, the main sources of risk and the main impact that regulation can have on risk patterns, then this framework is the appropriate set of criteria for ex ante system evaluation.

We turn in the next section to consider how these principles have been applied in the Australian context.

\section{Prudential Regulation in the 1980s: From Asset to Capital Regulation}

The arrangements for prudential regulation in Australia have changed considerably over the last thirty years or so. Prior to the Global Financial Crisis, two changes in particular were important for shaping the structure of regulation: a move in the 1980s from regulating the asset side of banks' balance sheets to the liability side; and the creation of a new authority for prudential regulation in the late 1990s in response to the recommendations of the Wallis Inquiry of 1996-97. The first of these is considered in this section, while the second is considered in the next section.

Prior to the 1980s, regulation was specified by the Banking Act of 1945. In broad terms, this approach could be classified under the first of the categories identified by Bhattacharya, Boot \& Thakor (1998) and Mishkin (2001) but a number of commentators 
argue that the focus of this regulation was to provide a framework for the conduct of monetary policy and that any prudential effect was largely incidental (Hogan \& Sharpe 1990; Grenville 1991; Lewis 1997; and Thomson \& Abbott 2000). Under the Banking Act, banks were required to hold a specified proportion of their assets in liquid form, chiefly Commonwealth Government securities. The logic of this approach dated from the recommendations of the Royal Commission on Monetary and Banking Systems in 1937 (the so-called Napier Commission) which was itself a delayed response to the banking failures and severe economic recession of the 1890s. A number of banks failed and many small depositors lost funds in this financial crisis, with substantial effects on the real economy (Boehm 1971, pp.312-318; Merrett 2013). Many commentators blamed this crisis on excessive bank lending which fuelled a property boom and subsequent bust, causing bankruptcies, defaults and bank runs. The policy response of progressive political parties was to argue for the exertion of discipline over the banking system in order to prevent future occurrences of excessive lending. Nationalisation of the banks and the establishment of a central bank to regulate their behaviour were the two practical manifestations of this response. An inquiry to carefully analyse the crisis and recommend policies to avoid its repetition was, however, debated and contested but delayed due to the more pressing issue of Federation and then the outbreak of World War I. When the crash of 1929 and the Great Depression raised again the whole issue of financial disturbances and the role of banks in propagating them, an inquiry was established by the Lyons Government in 1935.

The key recommendations of the Napier Commission were for the imposition of controls on the volume of bank lending by the establishment of special reserves to be held by banks at the Commonwealth Bank and for controls over lending and deposit rates. These recommendations were implemented in 1942 under emergency powers available to the Government during World War II and then in the Banking Act of 1945 and the later Reserve Bank Act of 1959 (Bell 2004).

Over time, these instruments of monetary policy increasingly focused on control of the quantity of money in circulation and variations to required bank reserves were understood to affect the overall money supply within a money multiplier framework. The effect of locking up a significant proportion of bank liquidity and keeping interest rates low, however, was to ration bank credit in periods of strong growth and demand for bank lending. In these circumstances, banks were able to fund the best quality loans (Thompson 1991a, p.116) although qualitative guidance concerning the direction of lending from the 
central bank was part of the policy framework. Good quality loans and significant stocks of liquid assets thus produced what might be judged to have been a relatively safe banking system but the system also provided low cost funding for the large government debt that had accumulated during World War II.

As is now well understood, the approach to monetary policy conducted within this regulated framework became increasingly ineffective over the course of the 1970s. Potential borrowers who had been rationed by the banking system sought finance from alternative sources and provided the impetus for financial innovation via the development of non-bank financial institutions (NBFIs) such as finance companies, building societies, and merchant banks, as well as the bank bill market (Grenville 1991, pp.12-15). Thus while the central bank exerted control over the banking system and related narrow monetary aggregates, the share of banks in intermediated finance was falling significantly so that broader aggregates, which included deposits of NBFIs, were simply expanding. Milbourne (1990) examines how controls over bank interest rate and liquidity ratios interacted with large unfunded public sector deficits, arrangements for issuing Commonwealth Government securities and fixed exchange rates to frustrate the Reserve Bank's efforts to exert monetary control.

The policy response to this loss of monetary control was the dismantling of the regulatory apparatus that had been in place since World War II and an attempt to influence the volume of liquidity available to the entire financial system rather than simply the banks. This was designed to have an impact on interest rates generally in the economy and through interest rates on expenditures. In 1979 the Commonwealth Government appointed the Campbell Committee to inquire into the operations and efficiency of the financial system and the effectiveness of the regulatory system. Following the Campbell Committee's recommendations controls on bank interest rates were progressively removed, Commonwealth Government securities were sold by tender at market determined interest rates, bank liquidity ratios were no longer used in an attempt to influence credit growth, the exchange rate was floated and new banks were allowed entry to the system to increase competitiveness and efficiency.

These developments had, however, direct implications for prudential regulation in two separate ways. First, as outlined above, the apparatus which had been used to operate monetary policy was also that which had facilitated prudential regulation. This apparatus was not available following deregulation. Secondly, it was widely recognised that monetary policy would entail much greater variation in interest rates under the new 
approach which had the potential to be destabilising economically and financially (Grenville 1991, p.16). Greater attention would therefore have to be paid to the condition of financial institutions and their vulnerability to increased interest rate volatility. The Campbell Committee addressed this issue and recommended a new framework for prudential supervision based around the imposition of a capital adequacy requirements that were sensitive to the risks faced by each bank. Campbell's recommendations also addressed credit exposures, liquidity and liquidity support by the RBA, regulation of banking groups on a consolidated basis (i.e. including bank subsidiaries) and possible roles for external auditors as pseudo-bank examiners (RBA 1989; Thompson 1991a, pp.135-37). Reaction to these recommendations for prudential supervision was varied and included concerns about their potential for re-regulation (vide Hogan 1982; Hogan \& Sharpe 1983; and Valentine 1983). However when the RBA essentially adopted Campbell's approach, resistance gave way to concerns that the RBA was not being sufficiently prescriptive (vide Fraser 1990; and Thompson 1991b).

These conditions led to the first significant change to prudential regulation in Australia across the course of the 1980s. Thompson (1991a, p.119) describes this change as "evolutionary" and Hogan \& Sharpe (1990, p.129) summarise its development. ${ }^{6}$ It was characterised by two central features. The first was a change in the central principles governing regulation that moved it from Mishkin's asset restriction approach to his risksensitive approach. This change was most evident in the introduction of a formal requirement for the maintenance of bank capital in 1985 (see Reserve Bank of Australia, $1985)^{7}$ and especially in the adoption of the 1988 Basel Accord which linked minimum regulatory bank capital to the composition of bank assets in terms of risk class. Initially this change overlapped with liquidity requirements similar in structure to those of the pe1980 period but these were later phased out.

The second feature of the change that occurred to Australian prudential regulation in the 1980's was a shift from what Mishkin (2001, pp.13-14) calls a regulatory approach to what he calls a supervisory approach. The first is rule-based and focuses on the

\footnotetext{
${ }^{6}$ The progressive nature of the change in approach to prudential supervision that occurred during the 1980s is evident in the arrangements within the RBA for their oversight as pointed out by Hogan \& Sharpe (1990, p.128). In 1980 a small supervision unit was established within the Banking \& Finance Department to examine data requirements for assessment of a bank's health. In 1984 the Supervision Unit was given increased status and independence, and in 1988 a separate division was established within which the Supervision Department was one of two departments (cf. RBA 1991, 6; and Thompson 1991a, p.117).

${ }^{7}$ This capital requirement was initially set at a minimum of 8 per cent of a bank's assets.
} 
enforcement of rules such as the liquidity requirements of the pre-1980 system. The second focuses more on ensuring that that bank management practices are sound and deliver the kinds of outcome that rules are designed to achieve. The supervisory approach grants more flexibility in the way a particular bank achieves the desired outcome than does the rules based approach and can be summarised in the following quote from the RBA:

\begin{abstract}
The Bank's approach to supervision is predicated on the view that the prime responsibility for the prudential management of a bank's business lies with the bank itself. The Bank's system of supervision is directed toward satisfying itself that individual banks are following management practices which limit risks to prudent levels; and that banks' prudential standards are being observed and kept under review to take account of changing circumstances.
\end{abstract}

(Reserve Bank of Australia 1985; cf. Thompson 1991a, p.118)

The major change that occurred in Australian prudential regulation over the $1980 \mathrm{~s}$, therefore, involved both an increased reliance on the design of incentives to encourage effective risk management practices, and the maintenance of capital buffers between the main sources of risk and depositors funds. This emphasis on incentives may be characterised as a market-based approach to regulation and it coincided with a strong emphasis on markets and competition generally in the 1980s. This emphasis also informed the policy of increased competition in the banking sector (also recommended by Campbell though with a number of qualifications) and the entry of a number of new banks from 1985. The greater intensity of banking competition to which this led, preceded a period in the late 1980s of asset price inflation, high interest rates, then asset deflation, financial distress at some financial institutions, and eventually recession.

Gizycki \& Lowe (2000, p.181) argue that losses experienced by the banking industry in this period were larger than any since the crisis of the $1890 \mathrm{~s}$, amounting to $2.25 \%$ of GDP in 1990 or approximately one third of aggregate bank capital. A number of small banks suffered losses that exceeded shareholders' funds and two of the largest banks suffered significant capital reductions. A number of non-bank deposit-takers and insurance companies also ceased operations. However, despite the similarity of these events with those of the circumstances that led to the appointment of the Napier Commission in 1935, they were commonly interpreted as simply the results of an over-reaction to the removal of regulatory controls (e.g. Edey \& Gray 1996, p. 10). According to this view, bank managers were unaccustomed in the mid-1980s to lending in a deregulated environment, and with the added impetus of increased competition in the banking industry, credit 
standards were less prudent than they later became after the lessons of the subsequent bank losses and financial stress had been learned. ${ }^{8}$

Much (though not all) of this financial distress was experienced by non-bank deposit taking institutions which had been supervised by State-based regulatory authorities rather than the Reserve Bank (O’Brien 1993, pp.117-121; Lewis 1997, pp.239-40). The standard of regulation applied by these authorities was much less stringent than that applied by the Reserve Bank, and some attributed the bulk of financial institution losses of the period to this difference. This observation also led to calls for the standardisation of regulatory frameworks for deposit taking institutions around the country and this culminated in the creation of the Australian Financial Institutions Commission (AFIC) in 1992. The task of this body was to develop a common regulatory standard to which individual jurisdictions would voluntarily conform (O'Brien 1993, p.121) and this convergence occurred over the next couple of years.

But the market-based thinking around which the main deregulatory and re-regulatory developments of the 1980s were constructed, was to be taken further by the Wallis Inquiry commissioned to re-examine Australia's regulatory structure in the mid-1990s. We consider its work in the following section.

\section{The Late 1990s: The Creation of a New Authority for Prudential Regulation}

Shortly after the election of the Howard Government in 1996 the Wallis Inquiry was established to "analyse the forces driving change in the financial system and recommend ways to improve current regulatory arrangements" (Financial System Inquiry 1997, p.1). The earlier Napier and Campbell Inquiries had been appointed following periods of financial and economic distress. As argued earlier, the Napier Commission had been appointed following the asset price inflation of the 1880s and the subsequent deflation and economic recession of the 1890 s as well as a similar set of asset price dynamics in the 1920s followed by the Great Depression of the 1930s. The Campbell Committee had been appointed following the significant consumer price inflation of the mid and late 1970s occurring simultaneously with high levels of unemployment, and the perceived inability of monetary policy to cope with these phenomena.

\footnotetext{
8 The Campbell Committee explicitly warned, however, that rapid deregulation could lead to 'overaggressive' competition in the banking sector that could generate financial instability. See Australian Financial System Inquiry (1981, p.440).
} 
While Australia had experienced an episode of asset price inflation, deflation, recession and financial distress in the late 1980s and early 1990s, similar in character but smaller in magnitude to the 1890 s crisis described above, the Wallis Inquiry was appointed with a more forward-looking agenda. This agenda focused on another concern among regulators about a broader set of competitive responses being generated in Australia's deregulated financial markets. This was the so-called "blurring of traditional distinctions" between institutions such as banks and insurance companies and the emergence of the financial conglomerate which offered not only banking services such as deposits and loans but insurance and funds management services as well. Their emergence represented a response to the same competitive pressures which had led to a reduction in interest rate spreads and the unbundling of traditional banking services in the 1980s and 90s (Edey \& Gray 1996, pp.16-20, 24; Gizycki \& Lowe 2000, pp.194, 196). Single service providers such as mortgage originators had increased competition on lending rates while fund managers had done the same thing to deposits rates on the other side of the balance sheet.

In the 1990s, banks responded to this attack on their profitability in a number of ways. They unbundled services such as transactions deposits and short term savings deposits which had traditionally been offered together with cross-subsidisation for the former in terms of lower interest rates paid on the latter. Breaking the link between these services involved imposing fees to recover the costs of facilitating payments at the same time as paying more competitive interest rates on deposits. Banks also improved operating efficiency by reducing staff and branch numbers. In addition, assets that could be profitably shifted off the balance sheet were securitised with fee income earned for the service of establishing a relatively secure cash flow for institutional investors.

But an additional strategy was that of moving into the areas that had generated the competitive pressures. One of these was funds management. The objective was to use existing banking distribution networks, made up of branches and call centres, to market the products of subsidiaries, increasing product sales but at a lower unit cost than doing so independently since infrastructure was shared (Edwards 1999, p.110-111). Banks thus began moving into a wider range of financial service delivery and other financial service providers began offering bank-like products.

Two separate concerns were associated with the development of conglomerates which offered such a range of services. The first was the issue of competitive neutrality. As highlighted above, banks, at the time, were regulated by the RBA. Thus any conglomerate emerging as the result of a bank's acquisition of insurance or fund management businesses 
would face the prevailing system of banking regulation. However, where an insurance company offered bank-like services such as chequing accounts or mortgage loans, these same services would fall under non-bank regulations administered by a separate regulator, the Insurance and Superannuation Commission. Since capital charges on funds raised by banks were in general greater than those on funds raised by other institutions such as insurance companies, the latter benefited from a competitive advantage (see Edwards 1999, p.116).

The second concern was the possibility of increased systemic risk arising from the interaction of risk in the insurance or funds management arms of conglomerates with that in their banking operations. Mishkin (2001, p.17) suggests that this amount of risk is potentially non-trivial on account of the too big to fail doctrine. If governments are inclined to extend the GSN to cover losses associated with large financial institutions, such institutions need to be carefully regulated because they encourage greater than usual levels of moral hazard and adverse selection in terms of the analysis of section three above. Conglomerates are important in this respect both because they tend to be large and because they introduce new and potentially greater and more complex risks. For example, a general financial market downturn reflected by falling asset prices could lead mutual fund investors to sell their investments. A liquidity drain at open-ended funds leading to redemption suspensions, or falling liquidation prices at closed-ended funds leading to capital losses could, in the presence of asymmetric information, cause a transmission of withdrawals at a conglomerate's fund management business to its banking business (see Gizycki \& Lowe 2000, p.184, who describe problems of this kind in Australia in the late 1980s). Name or brand contagion of this kind thus represented a potential new source of risk of which regulators had little experience.

Dale (1996, p.225) argues that there are three ways in which these risks may be reduced. Firstly linkages between banks and other financial entities may simply be banned. Secondly, banks and non-banks may be allowed to coexist in a within a conglomerate but secure firewalls should be built between them to prevent contagion spreading from a non-bank firm to a bank. Thirdly, linkages may be allowed but the nonbank entity must be regulated to the same standard as the bank so that the amount of risk the non-bank generates if effectively reduced.

The Wallis Inquiry's analysis reflected these concerns and dealt with them in terms of their implications for the following aspects of the regulatory structure:

- the coverage of prudential supervision; 
- the possibility of combining regulation of all deposit taking institutions;

- the possibility of combining regulation of DTIs, insurance and superannuation; and

- the possibility for separating bank regulation from the RBA.

The Inquiry's analysis reflected to some degree the discussion of risk outlined in sections two and three above that emphasised the nature of financial promises and their degree of intensity (Financial System Inquiry 1997, p.190). This intensity was defined for a financial product in terms of its degree of capital certainty, the ease with which investors can assess its underlying risk, and the consequences of default. It argued that regulatory impositions should focus on the most intense financial promises which were, in order of importance, transactions balances, other traditional bank deposits and capital-guaranteed investments. It recommended that prudential regulation be imposed on "...institutions licensed to conduct the general business of deposit taking from the public, or offering capital backed life products, general insurance products or superannuation investments" (Financial System Inquiry 1997, p.306), implying that the scope of prudential supervision be increased to cover non-deposit taking institutions which should be done by a single regulator separate from the RBA. A single regulator with powers over all business types that make up financial conglomerates was the best way to ensure that regulation was competitively neutral, cost effective and sufficiently flexible across institutions that risks from banking and non-banking interaction could be given appropriate regulatory attention (Financial System Inquiry 1997, p.347). It was careful to argue, however, that this did not necessarily imply identical regulation for each type of institution or their products. Differences would be appropriate where the intensity of promise varied. For example, the intensity of promise by a bank to a depositor is greater than the promise by the issuer of a mortgage-backed security (that has been rated by an international ratings agency) to an investor. Thus the new arrangements would not be neutral between bank lending for housing (which is subject to a capital requirement) and lending by a loan originator that has been funded by mortgage-backed securities.

The Inquiry's final report also argued for allowing a holding company structure for conglomerates with banking and non-banking businesses conducted by separate subsidiaries of the holding company. This way appropriate firewalls could be built between the conglomerate's different operations and banks could be insulated from insurance and funds management risks (Financial System Inquiry 1997, p.345). 
Two principal concerns lay behind the recommendation for separating the single regulator from the RBA (Financial System Inquiry 1997, p.313). First, was the relationship between the Reserve Bank's lender of last resort support for the banking system and its role as regulator were this to be retained. On the one hand this combination of responsibilities could at times present the Bank with the temptation to offer last resort support to an institution that was likely to fail in the hope that it would recover and protect the Bank's reputation as regulator. This could be an expensive and wasteful conflict of interest. On the other hand this combination of responsibilities would lend support to a popular impression that a government safety net was provided for the banking system which the Inquiry explicitly recommended against.

The second concern was that the task of regulating conglomerates and diverse financial organisations was likely to be a challenging one. This was best approached as the sole focus of a newly chartered organisation rather than as an additional task for an organisation already responsible for conducting monetary policy, running the payments system and ensuring general financial system stability.

The Inquiry thus recommended that the Reserve Bank retain responsibility for these activities, that a new authority be established to oversee the prudential regulation of institutions, and that the Australian Securities Commission be revamped to oversee conduct within financial markets. Hogan (1997, 1999), Hogan \& Sharpe (1997a; 1997b) and Gizycki \& Lowe (2000, p.181) characterise this as a functional approach to regulation rather than an institutional approach since it separates the core function of delivering payments-related services, wider "banking" functions no longer unique to banks, and functions which can be performed by markets.

The Inquiry's recommendations were broadly accepted by the Howard Government and in July 1998 responsibility for prudential regulation of financial institutions was transferred from the RBA to the newly created Australian Prudential Regulation Authority (APRA). The RBA retained responsibility for monetary policy, the operation of the payments system, and general financial system stability.

The creation of APRA and the separation of central banking from prudential regulation responsibilities represented the most significant change to the institutional structure of financial regulation in Australia since the separation of the RBA from the Commonwealth Bank in 1959-60. One of the major changes that occurred in the area of prudential supervision as a result of this structural change was the introduction of the PAIRS/SOARS 
system $^{9}$ which rated the probability that each institution would be unable to honour commitments to its financial claimants and the impact that this will have on the financial system. It then directed supervisory attention to those institutions which received a high rating on this probability/impact combination. Supervisory attention involved on-site inspection, discussions with the institution's management and board, pressure from APRA, where appropriate, for the institution to make changes that would enhance financial safety, and on-going monitoring. It thus represented a significant intensifying of supervisory oversight which Hogan \& Sharpe (1990) had discussed a decade earlier.

A fundamental question, however, raised by the separation of the monetary policy and prudential regulations functions in Australia was whether the operation of these functions was enhanced by the separation or whether this change removed synergies that made the execution of these responsibilities more difficult. We return to consider these issues later in the light of developments emerging from the Global Financial Crisis. We first, however, consider some important changes in international thinking about prudential regulation that occurred in the lead up to the crisis.

\section{The Development of Basel II}

By the time the first Basel accord had been operating in Australia for a decade or so, a number of shortcomings with its operation had been identified. Basel II extended the Basel I framework in a way designed to overcome these shortcomings. One of the most important of these shortcomings was that the structure of its risk-weighting scheme could have the opposite effect to that it was designed to have, and cause bank managers to take on more risk under certain circumstances. This effect was the result of attaching a riskweighting of 100 percent to all corporate loans irrespective of the party to whom the loan was made. Thus in circumstances of intense competition for market share, and especially when interest rates were rising, a bank manager might be tempted to increase the proportion of higher risk loans made at higher, more profitable interest rates because under the best outcome this would increase bank profits without incurring any additional capital requirements even though it also increased the probability of the bank experiencing a higher volume of defaults.

The Basel II regime attempted to address these problems in a number of ways. It was structured into three regulatory dimensions or pillars (Basel Committee on Banking

\footnotetext{
${ }^{9}$ The Probability and Impact Rating System (PAIRS) and the Supervisory Oversight and Response System (SOARS) were introduced in October 2002 (see APRA 2003a).
} 
Supervision 2006, p.2; Docherty 2008; and Terry 2009). Under Pillar I, a bank was required to hold capital against significant risks in its operations with three major differences over Basel I. The first was that the risk weights attached to loans were more sensitively related to the credit risk of the loan. This applied as much to corporate loans as it did across the full range of bank asset classes. The second of Basel II's Pillar I innovations was that three alternative methods were specified for the calculation of risk weights and capital charges. The "standardized approach" determined credit risk using external credit ratings for the borrower and then applying a risk weight for the resulting external rating (Basel Committee on Banking Supervision 2006, p.19). For example, loans to a borrower-rated AAA by a credit-rating agency would be risk-weighted at 20 percent, and 8 percent of the resulting risk-weighted loan value would have to be held as capital against this loan. The "foundation internal ratings (FIRB) approach" allowed a bank to use its own internal model for calculation of the probability of default for loans in particular classes and then imposed estimates for the losses that arose from default determined by the bank regulator to calculate the bank's risk-weighted exposure and the resulting capital charge. The "advanced internal ratings (AIRB) approach" allowed a bank to use its own estimates for all of the relevant risk variables to determine the capital charge. Some restrictions were placed on which banks could use the more advanced methods given their technical complexity, and internal systems had to meet strict standards to qualify for continued use.

The third innovation of Pillar I was that an additional capital charge was introduced against operational risk, the risk that a bank's systems may fail to identify and prevent fraud or serious mistakes in planning, calculation, or execution of standard operating procedures that led to significant losses with the potential to threaten the viability of the bank.

Pillar II of the new framework acknowledged the existence of risks not fully captured by the procedures outlined under Pillar I (Basel Committee on Banking Supervision 2006, p.204). These included risks such as those arising from high concentrations of lending to particular industries or geographical areas that were acknowledged under Pillar I but difficult to incorporate into the Pillar I calculations, risks not covered by Pillar I such as the impact on bank profitability and net worth of interest rate changes, and risks arising from factors external to the bank such as variations in the business cycle. Pillar II gave the prudential regulator the authority to inspect various dimensions of a banks' operations and 
to require banks to hold additional capital above that mandated by the application of Pillar I.

Pillar III was aimed to increase the level of market discipline faced by banks. It required disclosure of information to the market about a bank's risk profile, risk management procedures, and overall capital position so that banks pursuing excess risk would not only face tough capital adequacy requirements but would be subject to increased sale of their securities by better informed market traders, depressing security prices and increasing the cost of bank funds. Managers would thus have an increased incentive to modify the bank's risk profile or face discipline from stockholders. This dimension of the Basel II changes was designed to enhance the market mechanism for restraining bank risk-taking behaviour identified by Hogan \& Sharpe (1990), Dowd (1996) and Mishkin (2001). However, this mechanism was intended to complement broader regulatory objectives in Basel II rather than to replace them.

Basel II thus represented an attempt to improve the effectiveness of the prudential regulation of banks in order to reduce the likelihood of serious disruption to the financial system and thus to losses of depositor funds and reductions in GDP growth and employment. It was in the process of being implemented around the world including in Australia (See Docherty, Terry \& Trayler 2004) when the Global Financial Crisis struck, and interestingly, the United States was one of the slower countries to embrace its introduction.

\section{Key Features of the Global Financial Crisis}

Sufficient time has now elapsed since the onset of the Global Financial Crisis for a range of perspectives on its causes to have been offered. These perspectives variously attribute the crisis to loose macroeconomic policy settings (Taylor 2009), excessive subsidization of mortgage risk for low income borrowers (Calomiris 2011), increased income inequality that caused households to finance spending with more highly leveraged balance sheets (Stockhammer 2011), financial deregulation and increased innovation across the 1980s and 90s (Crotty 2009), or some form of Minsky financial instability process (see, for example, Kregel 2008, Wray 2009 and Dymski 2010 among many others). Whatever the underlying causes of the crisis, it seems clear that the crisis involved the substitution of traditional banking services with new financial instruments and markets, increased household leverage and default risk, inflation of U.S. housing prices, an eventual reversal of demand for housing culminating in a collapse of housing prices, the realization of 
accumulated default risk, and significantly increased loan losses for institutions holding mortgage debt instruments (see Cohen \& Remolona 2008; and Brunnermeier 2009).

Allen \& Santomero (1997, 2001), Hogan (1999) and Gizycki \& Lowe (2000) each document how the kinds of development considered in Section 5 above led to changes in the nature of financial intermediation across the 1990s where key banking services were replaced by the emergence of new financial instruments and markets in which these instruments could be traded. They argue that the nature of banking was thus transformed in this period from the traditional form of accepting deposits and making loans to the provision of loan origination and risk management services.

Brunnermeier (2009, pp.78-80) argues that the structuring of securitization vehicles and the short maturity of instruments issued to finance these vehicles were critical determinants of the extent of the crisis. Firstly, the structuring of high risk mortgages into special purpose entities (SPEs) transformed them in such a way that collateralised debt obligations (CDOs) with an investment grade credit rating could be issued against them. ${ }^{10}$ Secondly, the short maturity of these CDOs, mostly asset backed commercial paper (ABCP) issued to U.S. pension and mutual funds, exposed SPEs to significant liquidity and rollover risk. The result of these features was that high risk long term mortgages came to be financed by short term instruments held by pension and mutual funds that needed to be rolled over on a regular basis.

These features encouraged credit standards to fall in the years before the crisis because there was reduced incentive for banks to properly evaluate housing loans and because credit rating agencies (CRAs) inadequately appraised the riskiness of CDOs (Brunnermeier 2009, pp.81-82; cf. Cohen \& Remolona 2008, p.11; Docherty 2010). Banks faced reduced incentives to carefully evaluate loan risk because loans were moved offbalance sheet and only those loans in the securitisation pipeline were perceived to pose a genuine threat to the originating bank. CRAs on the other hand faced a now well documented conflict of interest given that the securities being rated were issued by the same institutions which were paying for CRA services (see Skreta \& Veldcamp 2009).

\footnotetext{
10 This structuring involved the division of mortgages into tranches, the most senior of which were "overcollateralized", i.e. secured against the cash flows of loans in junior tranches (Kregel 2008, p.10). It also involved the provision of credit enhancements that improved the credit quality of CDOs issued against mortgage loans held in SPE structures. Credit default swaps (CDSs) issued by monoline insurers (and in some cases by the originating banks themselves) provided compensation in the event of specified loan default. In addition, back-up lines of credit from originating banks provided SPEs with emergency liquidity should loan delinquencies or the realisation of liquidity risk from funding instrument rollover difficulties make payment of interest obligations difficult (Reserve Bank of Australia 2007, p.32).
} 

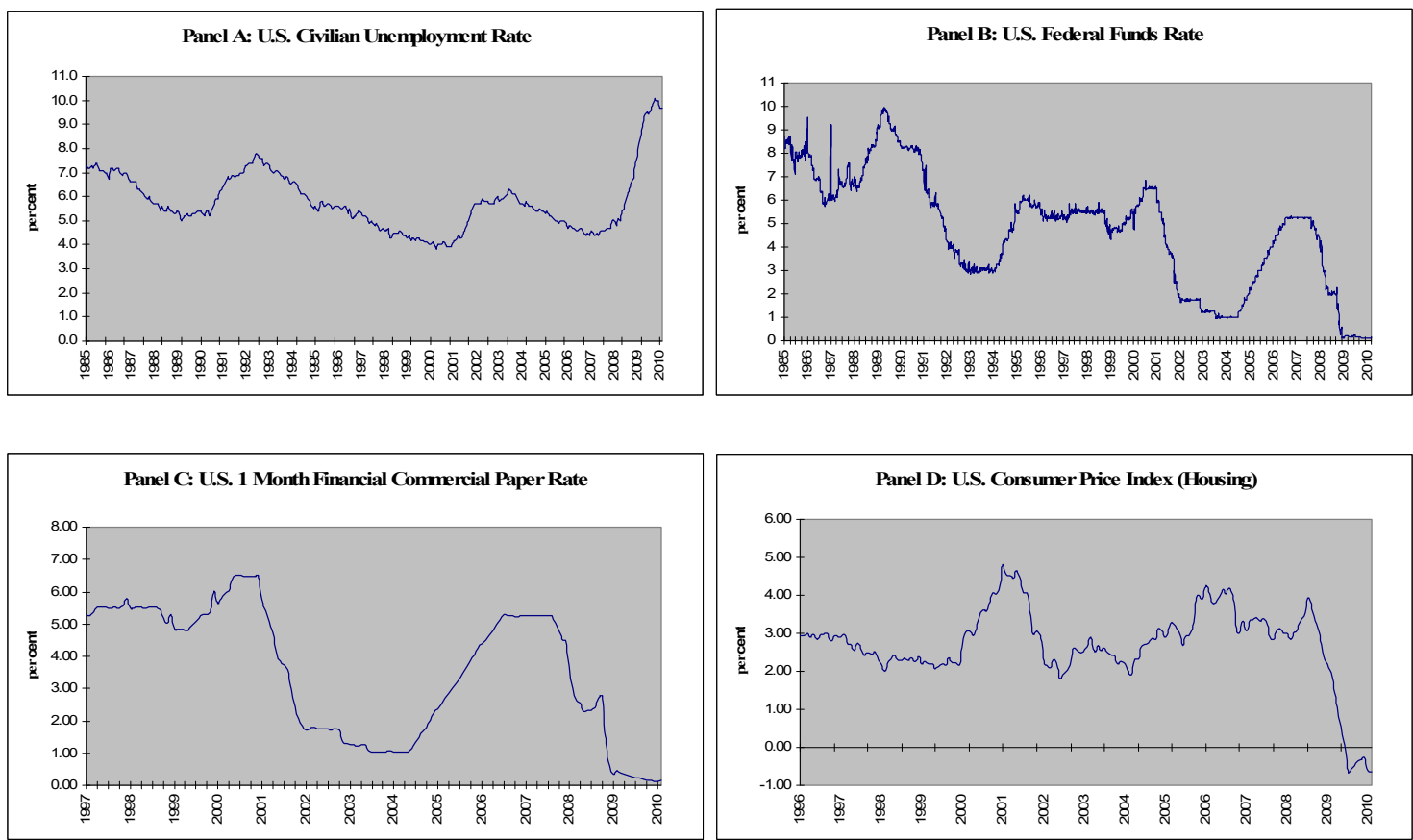

Figure 1: U.S. Unemployment, Interest Rates and Housing Costs

Sources: Federal Reserve Bank of St Louis, FRED Database, U.S. Department of Labor: Bureau of Labor Statistics, and Board of Governors, Federal Reserve System. UNRATE, Civilian Unemployment Rate, monthly, seasonally adjusted; CPF1M, 1 Month AA Financial Commercial Paper Rate, monthly; FF Effective Federal Funds Rate, weekly; CPIHOSSL, Consumer Price Index for All Urban Consumers: Housing, monthly, seasonally adjusted.

Of course the behaviour generating the first of these effects ignored the fact that banks securitising sub-prime loans were often providing emergency lines of credit to the SPEs purchasing these loans. This generated significant operational risk since credit departments appeared to be unaware of the residual exposures their banks would have to the poorly evaluated loans being originated. Cohen \& Remolona $(2008$, p.11) argue that the second credit standard-reducing effect where CRAs incorrectly evaluated the riskiness of CDOs issued by SPEs against sub-prime loans was caused by the particular combination of structuring, over-collateralisation and credit enhancement that made the risk features underlying CDOs highly complex. CRA miscalculation of these risks was thus simply part of the learning process associated with this kind of financial innovation. Brunnermeier (2009, p.81) argues that the key problem for CRAs was the lack of availability of historical data on mortgage default and delinquency rates underlying these CDOs. Either way, the traditional evaluators of credit risk appear to have increasingly neglected their task and the parties upon whom this task fell appear to have been poorly equipped for it. As the demand for housing finance and the market's appetite for CDOs steadily grew through the boom in U.S. housing prices following the bursting of the dot com bubble, the incentive for all parties to originate and securitise loans also grew and 

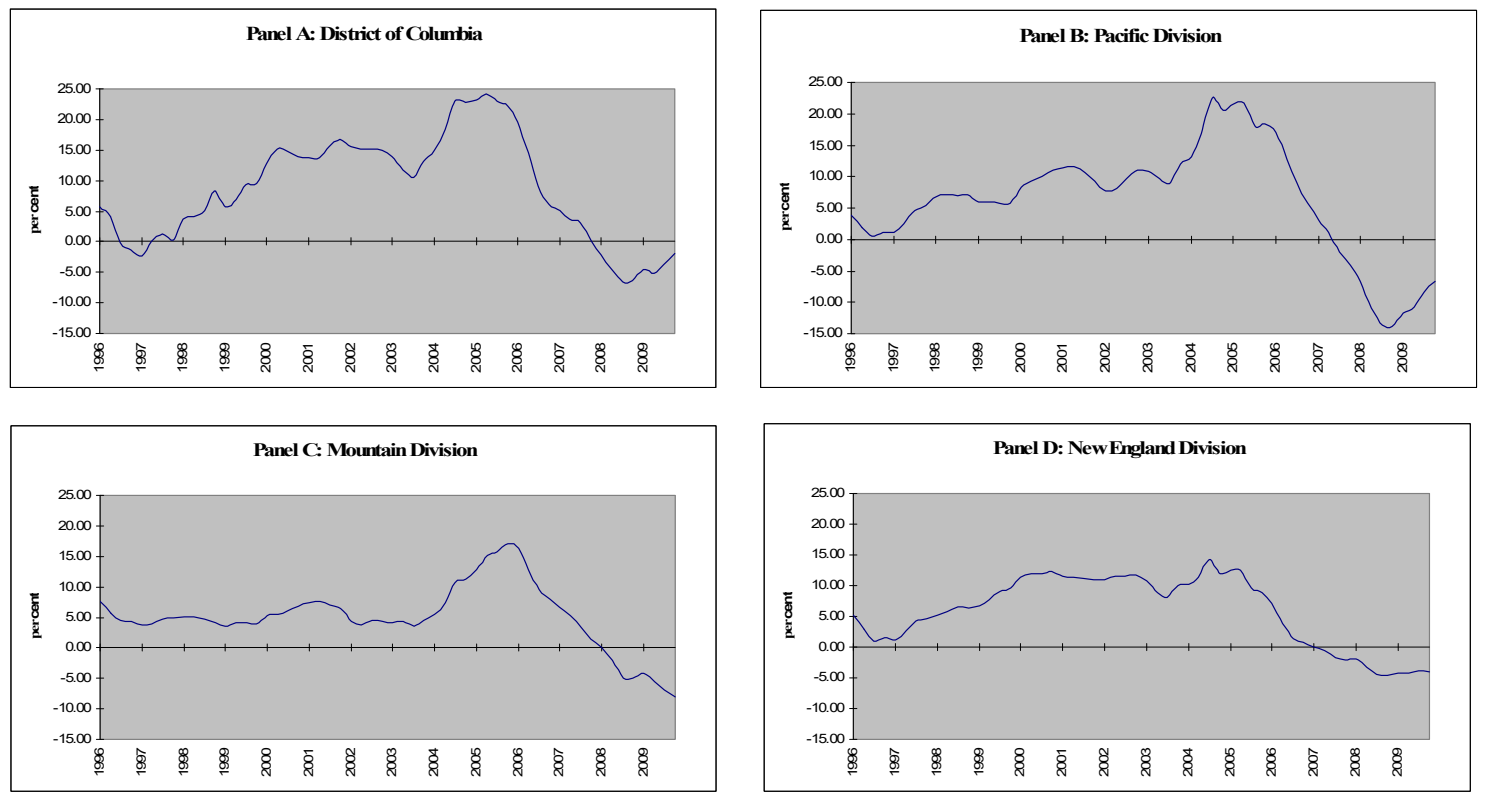

Figure 2: Selected U.S. Regional House Price Index, Annualised Rates of Growth Sources: Federal Reserve Bank of St Louis, FRED Database and U.S. Federal Housing Finance Agency, Census Division House Price Indexes, various, quarterly, not seasonally adjusted.

attention to loan quality fell given the changing pattern of responsibilities for risk evaluation.

Kregel (2008, p.9) argues that default rates on mortgages underlying the CDOs issued by SPEs ultimately increased because unemployment among sub-prime borrowers increased, their incomes and loan-servicing capacity fell, interest rates on sub-prime loans increased, and house prices declined sharply. The last of these developments ensured that adequate security was not available to cover outstanding balances on defaulted loans. These developments are shown in Figures 1 and 2. Panel A of Figure 1 indicates that U.S. civilian unemployment began rising from 2001, following declining GDP growth in the aftermath of the dot com bubble deflation. Unemployment reached a pre-crisis peak of approximately $6.0 \%$ in 2004 . Short term interest rates on which the pricing of SPE the prime loans were based, began rising from 2004 as indicated in Panel B of Figure 1. The Federal Funds Rate had been cut in 2000 following the bursting of the dot com bubble, but this trend was reversed in 2004 with the rate reaching its pre-crisis peak of $5.00 \%$ in $2006-$ 2007. Panel C indicates that this had a flow-on effect to rates on highly rated commercial paper. These two effects led to increased defaults on sub-prime loans from 2005 (Reserve Bank of Australia 2008b, p.5).

These developments then led to slower growth in house prices as sales of foreclosed properties began to increase about this time. Panel D of Figure 1 indicates an increased 
cost of housing between 2002 and the onset of the crisis in 2007. Figure 2 shows the behaviour of house price indexes for U.S. census divisions which showed some of the sharpest declines from the beginning of 2006. This process began to translate loan defaults into SPE portfolio losses. Two immediate effects followed. First, depressed SPE asset values were increasingly reported in the first half of 2007 (Brunnermeier 2009, p.83). In the light of these losses, CRAs began to revise their ratings of CDOs backed by sub-prime mortgages downwards and this had two further results: it raised questions about the general reliability of credit ratings for a range of CDOs; and it refocused attention on the problem of correctly valuing the assets which backed CDOs.

Brunnermeier (2009, p.84) shows that these effects resulted in a sudden and dramatic reduction in the value of asset backed commercial paper on issue from July 2007. One month later the LIBOR-OIS spread jumped dramatically, signaling the first freeze in interbank lending (Cohen \& Remolona 2008, p.9). These events parallel the features of classic bank runs described in Section 3 above. The complex nature of CDOs suggests that they were characterised by asymmetric information. When the loans backing them experienced significant defaults, the response of investors was to sell, the equivalent of withdrawing deposits from traditional banks. The resulting drying up of the ABCP market thus constituted the equivalent of a bank collapse. While a similar phenomenon in the interbank was more complex, it shared the same basic features as the drying up of the ABCP market. A number of banks had residual exposures to SPEs on account of back-up lines of credit and credit enhancement services to SPEs so that the decline of investor interest in rolling over short term funding for these vehicles brought exposure to them back on to the balance sheets of the originating banks.

While the provision of liquidity by central banks around the world alleviated the initial interbank crisis and the assisted takeover of investment banks who's SPEs had experienced large sub-prime losses restored some confidence in $\mathrm{ABCP}$ markets, the volume of defaults continued to rise. Towards the end of 2007 and into 2008, monoline insurers suffered significant losses on credit default swap exposures to SPEs and were threatened with credit downgrades by CRAs. Given that these insurers provided credit enhancement services to a range of other security issues including municipal bonds, their downgrading reduced the effective credit rating of downstream securities causing pension funds to divest these securities, falls in their prices, and losses for a range of funds continuing to hold these securities. The flow-on effects had a significantly negative impact on hedge funds operated by U.S. investment bank Bear Stearns in May 2007 
which the U.S. Treasury assisted to be taken over JP Morgan Chase, and eventually in September 2008 by Lehman Brothers which the U.S. Government decided, of course, not to assist. The resulting uncertainty about the credit quality of virtually every institution and security issue except the direct issues of sovereign Governments, caused the 3 month LIBOR-OIS spread to rise significantly and the rate of 3 month U.S. Treasury bills to fall almost to zero (Reserve Bank of Australia 2008b, p.12). The increased demand for liquidity was so large that the interbank market ground virtually to a halt necessitating a range of unprecedented market interventions by governments and central banks around the world.

In summary, the Global Financial Crisis was due in large measure to a decline in credit standards associated with a trend in financial systems over the last twenty years whereby the traditional function of banks was progressively transferred to a series of interconnected markets. It also occurred against the background of sustained increases in the price of housing and the growth of credit to finance this house price inflation.

\section{The International Response to the Crisis}

The first considered responses of the international regulatory community to the GFC were outlined in the Report of the Financial Stability Forum (FSF 2008) to the G7 Ministers and Governors in April 2008 and in The Basel Committee's Response to the Financial Crisis: Report to the G20 (BCBS 2010a) published in October 2010. In each case, the GFC is broadly understood in terms of the analysis offered in Section 7 above. The Report of the Financial Stability Forum, for example, stresses the long period of "benign economic and financial conditions" of the 1990s (FSF 2008, p.5) characterised by low interest rates, plentiful liquidity, a strong and increasing appetite for risk on the part of investors, and an eventual "loosening of credit standards" especially in the U.S. banking industry.

This Report also emphasised the evolution of financial innovation throughout this period in the form of increased securitisation and the development of structured products which fuelled credit growth, increased leverage and rising asset prices. The most fundamental problem, however, according to the Report was the poor management of risk that mounted alongside these trends. The eventual realisation of this risk was triggered by the weakening U.S. housing market and increased loan delinquencies. As sub-prime defaults increased, flow-on effects to structured investment vehicles, investors exposed to these vehicles, and those exposed to these investors came to be felt. The problems for 
"sponsoring banks" that provided enhancements to structured investment vehicles were also noted, especially the provision of standby credit facilities and the resulting disruption to international funding markets (FSF 2008, pp.6, 16). Policy responses suggested in the Report include the need for increased levels of bank capital and the coverage of capital requirements to include securitisation and bank exposures to structured credit instruments, stronger liquidity requirements to reduce the impact on banks of funding problems caused by the ceasing up of wholesale markets, increased market transparency, and improved valuation methodologies for market traded instruments.

The Basel Committee's Response is, not surprisingly, more focused on dimensions of the crisis associated with regulatory failure or aspects of the crisis which might have been prevented or mitigated by better regulation. It thus emphasises inadequate levels of bank capital, insufficient liquidity in the advanced phases of the crisis and procyclicality of deleveraging processes initiated by the crisis.

In terms of policy responses at the international level, these were made in two stages. The first was to introduce immediate revisions to the Basel II framework that addressed problems discovered to have been at the centre of the crisis. Basel 2.5, as it was called, was released in July 2009. It required banks to hold additional Pillar I capital against certain securitization and re-securitisation exposures and to undertake more rigorous assessment of externally rated exposures (See BCBS 2009). These changes were supposed to be adopted in participating countries by December 312010 .

The second stage involved a more considered reflection on the causes of the crisis and the implications this might have for bank regulation. The results of this process were outlined in BCBS (2010a, pp.1-3). It led to three broad modifications of the Basel 2.5 framework: an increased capital requirement, expanding the range of activities covered by the core capital ratio; a new liquidity requirement which had been viewed as unnecessary under the previous capital-focused framework (see, for example, Hogan \& Sharpe 1990, p.134); and the incorporation of a new idea in prudential regulation, that of macroprudential capital requirements which attempted to account for changes in systemic risk across the economic cycle to which the contributions of Minsky (1964), Kindleberger (2000) and Borio (2005), considered earlier in the paper, drew attention.

The first of these modifications designed to strengthen capital requirements included: the introduction of a minimum funding of $4.5 \%$ of risk weighted assets in the form of common equity instruments that can be fully used to absorb losses (BCBS 2010a, p.5; BCBS 2011, p.12); a minimum tier 1 capital of $6.0 \%$ and total capital of $8.0 \%$ of risk- 
weighted assets to be observed at all times; a so-called capital conservation buffer (CCB) that comprises common equity of $2.5 \%$ above the minimum capital requirement which must be held "outside periods of stress" with rules to replenish capital if stress periods reduce common equity below a total of 7.0\% (BCBS 2011, p.54); and minimum leverage ratio (Tier 1 capital to total (non-risk weighted) assets) of 3\% (BCBS 2011, pp.61-62). Basic capital requirements were thus tightened by these measures with a greater emphasis on core instruments capable of absorbing losses in periods of stress and a build-up of such instruments in good times that can be called upon in bad times. Thus under the CCB, common equity must be $7.0 \%$ of risk weighted assets outside periods of stress, but if this ratio falls to between $4.5 \%$ and $7.0 \%$ during periods of stress, capital conservation rules kick in to limit the distribution of dividends, the undertaking of share buy backs, or the payment of staff bonuses so that earnings are retained to rebuild or "conserve" capital. The lower is the ratio of common equity to risk weighted assets in this range, the greater is the proportion of earnings that must be retained to rebuild the capital ratio. "This promotes the goal of mitigating pro-cyclicality in the banking and broader financial system" (BCBS 2010a, p.9).

The second modification introduced by Basel III introduced more explicit liquidity requirements for banks into the prudential regulation mindset and had two dimensions: the liquidity coverage ratio (LCR) and the net stable funding ratio (NSFR). The first required banks to forecast liquidity needs over a thirty day stressed scenario, and to ensure that sufficient assets, meeting specified liquidity characteristics, were held on the balance sheet to meet these liquidity needs. Secondly, the NSFR had a longer horizon of twelve months and required banks to demonstrate the availability of stable sources of funding across this timeframe, contrasting with the experience of some institutions that relied heavily on wholesale borrowing in their liquidity management strategies and thus experienced liquidity-related stress during the crisis.

The third modification of the Basel III regime was built around a counter-cyclical capital buffer (CCCB) and adjusted the range of the CCB when the regulatory authority judges that credit growth has risen to "excessive levels" (BCBS 2010a, p.7). If the regulator believes that excessive credit growth is generating a build-up of system wide risk they may put in place an additional countercyclical buffer requirement of between 0 and $2.5 \%$ of risk weighted assets depending on the perceived extent of the increased risk (BCBS 2011, p.58). They should, however, give 12 months' notice of their intention to impose this additional requirement. The principal idea of these macroprudential measures 
was to recognize the systemic effects that a generalized expansion of credit during a boom phase could have on asset prices and private balance sheets. Since increased leverage could be associated with increased demand for financial assets and higher asset prices, and since higher asset prices could subsequently unwind, these "financial imbalances" were seen as undesirably contributing to greater systemic risk. The CCCB provisions thus provided a tool for leaning against credit expansions that might be causing a build-up in "financial imbalances". ${ }^{11}$ Increasing the requirement of banks to fund loans which may be fueling such imbalances with additional capital was designed both to discourage such loans and to build up additional capital protection in case they suddenly unwound (See 2010a, p.7; 2011, p.57ff; cf. Borio 2005; Docherty 2008; Hanson, Kashyap \& Stein 2011; Haldane 2012; and Galati \& Moessner 2013). ${ }^{12}$ The final versions of the overall Basel III architecture were outlined in BCBS (2011) and BCBS (2013).

As we shall see in the next section, Australia essentially adopted the new Basel III structure with one or two reservations and modifications.

\section{Australian Prudential Regulation after the Global Financial Crisis}

An important insight into understanding the changes to Australia's system of prudential regulation after the Global Financial Crisis may be gained by understanding how the crisis and its impact on the Australian financial system were perceived by Australian regulators. These perceptions could have been expected to frame the nature of the problems in the Australian financial system thrown up by the crisis to which subsequent changes in regulatory structures were then adopted as solutions. An indication of these perceptions is available from the RBA's bi-annual Financial Stability Review published from the time the crisis began to break, from speeches made by RBA officials over the same period, and from APRA's Annual Reports.

Characterisations of the crisis contained in the RBA's Financial Stability Reviews published from early 2008 were largely in keeping with the description of the crisis outlined in Section 7 above. The main element in these characterisations was the underpricing of risk that had occurred during the pre-crisis boom period and the re-pricing which began as risks associated with sub-prime loans began to be realised in 2007 and

\footnotetext{
${ }^{11}$ The RBA and APRA (2012, p.19) challenge this characterisation but we defer more careful consideration of it until later in the paper.

${ }^{12}$ Hanson, Kashyap \& Stein $(2011$, p.17) point out that this argument assumes a constant cost of equity finance for banks. They point out, however, that reductions in perceived risk associated with increased capital ratios may reduce the cost of banks equity funding and leave the overall average cost of bank funding unchanged which implies no necessary change in the interest rate banks would need to charge on loans of this type.
} 
2008 (See, for example, RBA 2008b, pp.1-6). The associated loss of confidence in banks exposed to these losses, the increase in demand for liquidity by banks and a variety of other agents, the closing down of inter-bank markets for liquidity, and falling prices across a range of financial assets were also major themes.

Not surprisingly, these characterisations were echoed in speeches given by RBA officials over the same period, sometimes with explicit reference to Bank policy statements. ${ }^{13}$ In early 2008, Governor Stevens emphasised the role of financial capital flowing out of China in the 1990s that persistently lowered interest rates in global financial markets and generated a "search for yield" that made investors attuned to investments of reasonable quality offering higher returns than those available on standard financial securities (Stevens 2008, p.21). This coincided, he argues, with the "great moderation" and a reduced perception of risk supported by low default rates on corporate debt across most of the 1990s and early 2000s. In this environment, investors took on greater risk with higher leverage that was readily facilitated in a world of accommodating financial institutions. But, he points out, "something was going to occur that would trigger a reappraisal of risk" (Stevens 2008, p.22) and this trigger was a series of increased losses in 2007 on US sub-prime mortgages that affected the value of hedge funds and structured investment vehicles. This led to a reduction in demand for asset-backed commercial paper, the triggering of stand-by liquidity facilities offered to the issuers of this paper by US banks, bank stress, increased uncertainty about a variety of counterparty exposures, and the resulting increase of liquidity preference and the closing of interbank markets (Stevens 2008, p.22). This perception of the crisis also corresponds closely with that outlined in Section 7 above. It broadly coincides with treatments in Lowe (2008, p.80), Edey (2008), who places greater emphasis on the real economic effects of the crisis, and Ellis (2009), who provides more detail on the mechanics of the financial accommodation of sub-primes mortgages.

Characterisation of the impact that the crisis had on the Australian banking system in both the Financial Stability Review and in speeches by senior Bank staff in the post-crisis period stressed the fundamental health of the Australian system and the indirect nature of the impact that the crisis had on this system. In particular, various editions of the Review highlighted the profitability and strong capitalisation of Australian banks, very low bank exposures to sub-prime loans or related instruments, the high quality of bank assets, and

\footnotetext{
${ }^{13}$ Stevens (2008, p.20), for example, refers to the March 2008 Financial Stability Review, and Edey (2008, p.19) appears to refer to the October 2008 Statement on Monetary Policy.
} 
the low ratio of non-performing loans to total loans outstanding. ${ }^{14}$ The main indirect effects of the crisis on the Australian system was the increased cost of offshore wholesale funding and the sudden closure of markets into which residential mortgage backed securities (RMBS) could be issued. Banks that relied, therefore, on such wholesale sources to finance their loan books were in a weaker position than banks which had been relying on traditional deposits. The transmission of these effects to the real economy were felt as banks raised their lending rates (particularly on business loans) and tightened credit standards which reduced loan supply to some degree. Banks also held more liquid assets and lengthened the maturity of their liabilities where possible (RBA 2009a, p.2). Stevens (2008, p.20) reiterates the importance of bank profitability and strong capital positions, and Lowe (2008, pp.81-82) reiterates, adding that loan arrears were also low for Australian banks across the crisis period and credit quality was high, observations further confirmed by Ellis (2009, pp.31-32).

What is particularly interesting, however, is the ascription of this superior performance of the Australian banking system in all of these publications in large measure to prudential regulation.

In this difficult environment, Australia has benefited from having strong and profitable financial institutions with few problem assets on their balance sheets, and a sound regulatory regime.

(Financial Stability Review, September 2008, p.2; emphasis added)

... but the main reason for the resilience [of the Australian financial system] is many years of robust economic growth, sound regulatory foundations and prudent risk management."

(Stevens, 2008, p.20; emphasis added)

Lowe (2008, pp.83-84) provides perhaps the most comprehensive treatment of this subject offering three reasons for the superior performance of the Australian system: an absence of "competitive excesses" in Australia relative to the United States that meant credit standards did not fall as far in Australia as they did in the United States; an Australian regulatory regime in which APRA played an active role in supervising the providers of housing finance and "tightening up prudential requirements on housing loans" in the years leading up to the crisis ( $c f$. Ellis 2009, p.32); and Australian legal arrangements where the

\footnotetext{
${ }^{14}$ See, for example, RBA (2008a, pp.23-26; 2008b, pp.21-25; 2009a, pp.17-24; 2009b, pp.17-23; 2010, pp.17-22). The following assessment of the Australian banking in 2008 was typical of this period: "The Australian financial system has coped better with the recent turmoil than many other financial systems. The banking system is soundly capitalised, it has only limited exposure to sub-prime related assets, and it continues to record strong profitability and has low levels of problem loans. The large Australian banks all have high credit ratings and they have been able to continue to tap both domestic and offshore capital markets on a regular basis." (RBA, Financial Stability Review, p.1)
} 
Uniform Credit Code imposes effective penalties on credit providers that take insufficient care in the credit assessment process and where Australian borrowers cannot walk away from housing loans as easily as they can in the United States.

Turning to the prudential regulator itself, APRA's Annual Reports between 2008 and 2010 paint a similar picture to that outlined by the RBA. There is, however, less detail on the broad nature of the crisis internationally and much more detail on the effects it generated for the Australian system. In terms of the broad character of the crisis, the 2008 Annual Report attributes the turmoil to two principal causes: poor credit standards on the one hand; and poor risk management of structured investment securities on the other (see APRA 2008, p.4). In terms of the impact of the crisis on the local financial system, the 2008 Report observes no close parallels of the international problems in Australia that could directly affect the local banking system but it does list a series of secondary effects. The first of these was the reduced availability of liquidity and the associated increase in the cost of wholesale funding occasioned by the dramatic loss in confidence with banks, even by other banks, during the crisis (APRA 2008, pp.4-5). This was discussed above. The importance of this effect from APRA's perspective is indicated by the attention paid to it in APRA's supervisory engagement with the deposit-taking sector during the crisis. APRA reports closely monitoring the liquidity positions and management strategies of all deposit-taking institutions during the crisis (see APRA 2008, pp.10-12; 2009, pp.15-16; and 2010, pp.14-15) and working closely with the RBA to identify likely points of weakness in the system with respect to the availability of liquidity (APRA 2008, pp.1011).

A second indirect effect identified by APRA was the exposure of some larger ADIs to borrowers whose business models relied heavily on funding from international wholesale markets and who therefore came under pressure given the reduced availability and increased cost of funds in these markets during the crisis (APRA, 2008, p.12; 2009, p.16). A third effect was an increase in the rate of non-performing loans on the books of ADIs as the real effects of the crisis were disseminated internationally affecting mainly local small to medium enterprises that had borrowed from Australian ADIs. The level of these loans remained, however, well below their level in the 1990s recession (APRA 2009, p.16).

The APRA Annual Reports of this period also cast further light on references in the RBA's Financial Stability Reviews, Stevens (2008), Lowe (2008) and Ellis (2009) to the role of prudential regulation in generating the superior performance of Australia's banking sector during the financial crisis. The 2008 Annual Report makes a direct link between a 
"strengthening of Australia's supervisory framework" and recognition that Australia's financial system weathered the global crisis better than many of its international peers:

Over recent years, APRA has undertaken a major strengthening of Australia's supervisory framework aimed at reinforcing standards of risk management and prudent business behaviour in the Australian financial system and improving its resilience ... Australia's supervisory framework is widely to acknowledged to have performed well during the market turbulence and, operating within this framework supervised institutions largely avoided the financial market temptations to which some of their global peers succumbed.

(APRA, 2008 Annual Report, p.5)

This strengthening of the framework was centred around the PAIRS/SOARS system, discussed earlier, which rates the probability that each institution will be unable to honour its commitments and the impact of this on the financial system, and then directs supervisory attention to those institutions identified as potentially problematic.

The above analysis indicates the way in which the Global Financial Crisis and its impact was perceived by Australian regulators. Within this perception, the crisis was the result of the kinds of forces outlined in Section 7 that operated in other countries but where the associated risks were poorly managed by financial institutions and poorly regulated by financial supervisors so that a bubble was able to form in the US property market and to burst with not surprising consequences for investors in securitisation vehicles, traditional lenders and the real economy. Because these risks had been effectively managed in Australia, the consequences of the crisis for the local financial system were largely the indirect effects of the increased preference for liquidity that occurs during times of crisis, associated higher wholesale funding costs, the exposure of ADIs to borrowers adversely affected by these developments and the real effects of reduced aggregate demand in the international economy on local exports.

While the main modifications to prudential bank regulation implemented in Australia following the GFC largely reflected the new Basel III regime, they also make sense in light of the perceptions of the crisis and the impact of the crisis on the Australian banking and financial systems outlined above. In summary they involved clarification of the nature of the government safety net, strengthening of pre-GFC capital requirements for ADIs, the introduction of a new capital-based apparatus for engaging in macroprudential regulation, and a substantial strengthening of liquidity regulation. We consider each of these in turn.

As outlined above, when the crisis broke, despite being well capitalized and having non-performing loans well below the levels of troubled U.S. banks, Australian banks and other deposit-taking institutions experienced trouble rolling over maturing wholesale 
funding in international markets because of the increased uncertainty discussed in the previous section. The Australian Government thus introduced two schemes designed to ensure the continued availability of this funding and to strengthen depositor confidence in Australian banks. Under the first, the Australian Government Guarantee Scheme (AGGS), the Commonwealth Government guaranteed deposits and wholesale funding for eligible authorized deposit-taking institutions (ADIs) in amounts exceeding \$1 million. Institutions which made use of this guarantee were charged a fee but the scheme reduced uncertainty for Australian ADI creditors and ensured the on-going availability of funding to these institutions (see Schwartz 2010, pp.22-25). This scheme was always intended to be temporary and was closed at the end of March 2010. The second scheme, the Financial Claims Scheme (FCS), similarly involved a guarantee by the Australian Government for deposits at Australian ADIs up to \$1 million per depositor per bank (Schwartz 2010, p.20). This was designed to ensure that the contagion effects fueled by asymmetric information and the observation of losses at some deposit-taking institutions (in this case overseas) did not occur in the Australian context. Unlike the AGGS, however, the FCS was left in place after the crisis with coverage reduced from $\$ 1$ million to $\$ 250,000$ per depositor per bank from February 2012 (See Turner 2011).

The first set of developments in Australian arrangements affecting prudential regulation after the onset of the crisis thus involved resolution of the ambiguity around the concept of depositor protection. We saw above that Hogan \& Sharpe (1990) had identified this ambiguity and recommended that it be resolved by the introduction of a deposit insurance scheme. We also saw that the Wallis Committee had recommended against such a move. Clearly the FCS removed this ambiguity by making the extent of the government safety net (GSN) explicit, thus underscoring the need for well-designed prudential regulation to reduce any resulting moral hazard on the part of bank managers.

The second and third related developments in Australian prudential regulatory arrangements after the crisis has been the adoption of the Basel III capital regime and its macroprudential apparatus. The details of these arrangements are set out in APRA (2011) and changes to capital regulation were implemented in January 2013. The biggest potential change for the Australian financial system implied by the new framework was the introduction of the explicit apparatus that allowed for the conduct of macroprudential policy. Interestingly, the RBA and APRA have downplayed this issue by questioning the reliability of Basel III macroprudential tools, arguing that there are problems in the methods suggested by the Basel Committee on Banking Supervision (BCBS) for 
determining a reliable gap between credit growth and some non-asset-inflationary benchmark that can be used in setting time-varying capital requirements (see RBA \& APRA 2012, pp.19-20). The principal problem they raise is the possibility that significant increases in the ratio of credit to GDP may occur for reasons other than the emergence of asset bubbles and financial imbalances such as a response to financial deregulation or genuine capital deepening associated with rapid economic development. Australian regulators have thus signaled their caution in using this dimension of the Basel III regime.

The third major change in the Australian context has been the adoption of the Basel III liquidity regime (BCBS 2013). This was introduced in Australia at the beginning of 2015 and distinguishes between institutions to which the Basel III liquidity coverage ratio (LCR) regulations apply and so-called minimum liquidity holdings (MLH) deposit-taking institutions. For the latter, specified liquid asset holdings of cash, government and semigovernment securities, and bills or certificates of deposit issued by Australian ADIs must be at least $9 \%$ of liabilities (APRA 2014). A problem with the implementation of the Basel III LCR for other ADIs in the Australian context was the lack of a sufficient stock of Australian Government securities on issue since the characteristics of these instruments easily satisfy the criteria for high quality liquid assets (HQLAs) defined within the LCR and there are no obvious substitutes to hold in their place. To solve this problem, the RBA established the Committed Liquidity Facility (CLF) at the beginning of 2015. This facility provides ADIs with access to a pre-specified amount of central bank liquidity via repurchase agreements on a wider range eligible securities at a cost of 25 basis point above the RBA's target cash rate. APRA must approve of this arrangement for each ADI that wishes to use it and the RBA must also be satisfied with the financial condition of the ADI before a CLF will be established.

These changes to prudential regulation of deposit-takers in Australia after the GFC not surprisingly reflect the perceptions of Australian regulators about the nature and causes of the GFC and how it affected the Australian banking and financial systems outlined above as well as the new Basel III regime. The questions arises, however, as to how much of a fundamental change these modifications actually represented in comparison to the preGFC arrangements in Australia. Attention is given to this issue in the following sections.

\section{Evaluation of Depositor Protection and Liquidity Regulation Changes}

The introduction of the Financial Claims Scheme is a clear change and we argue that is it one to be welcomed. In some respects, however, it constitutes a clarification and 
formalisation of an existing perception within the Australian community suggested by the depositor protection provisions of the Banking Act rather than a fundamental change (cf. Harper 1997, p.298). There is an associated question raised by this development which is whether moral hazard associated with the scheme ${ }^{15}$ should be addressed by the imposition of a risk-based premium. We argue that a reasonable alternative to risk-based premia is to ensure that capital requirements are sufficiently risk-sensitive so that disincentives to risktaking are present within the regulatory system. Since the Basel III requirements meet this condition, we argue that risk-based deposit insurance premia are unnecessary. In addition, since the benefits of protecting the integrity of the banking system accrue to the entire economy and not just to depositors, it is appropriate that any cost associated with claims made under the FCS should be met from consolidated revenue rather than from a charge to depositors. We thus endorse, the ex-post funding arrangements for the FCS recommended by the recent Murray Inquiry (Financial System Inquiry, 2014, p.82).

The introduction of the new Basel III liquidity regime represents a more fundamental modification. As we saw earlier in the paper, the logic of capital regulation is to give bank managers the freedom to decide on the composition and risk profile of their asset portfolios but an incentive to be cautious and well considered about pursuing risky strategies by requiring them to fund such strategies with a greater proportion of capital. At the same time, capital requirements put in place a protective buffer between the value of risky loans and depositor funds. If such a regime is an effective way to manage risk, the logic of imposing liquidity requirements is not clear. Hogan \& Sharpe (1990) made this point two and a half decades ago. This was especially the case given the degree to which wholesale liquidity markets had developed in the 1980s and 90s, and the role of central banks within those markets.

The reason such requirements constitute part of the Basel III regime arises, of course, from the GFC experience in which those markets closed down. But two things should be kept in mind about this experience. Firstly, wholesale markets closed down at the height of the crisis because of acute uncertainty about the viability of banks internationally. This uncertainty was effectively generated by the realization of credit risk from poor lending decisions and ongoing bank exposures to this risk through securitization vehicle enhancements provided by banks despite risky loans having been moved off their balance sheets. These risks are, however, explicitly addressed by revisions to the Basel III capital

\footnotetext{
${ }^{15}$ See Henckel (2010) for a discussion of moral hazard specifically in relation to the AGGS and the FCS.
} 
requirements so that this particular cause for wholesale market shutdown should not be repeated. Secondly, central banks always have the ability to inject liquidity into wholesale markets where this is needed, and this was done during the crisis. Central banks around the world revised their lists of securities eligible under repurchase agreements precisely so that such injections could be made. This reflects a philosophy according to which the shutting down of wholesale markets is an extraordinary event to which monetary authorities can and should respond with extraordinary measures. According to this perspective, therefore, liquidity requirements in addition to well-designed capital requirements, are not needed.

The counter-argument in favour of the Basel III liquidity measures is that liquidity engenders confidence in financial institutions and minimum liquidity requirements should, therefore, be mandated (Dow 1996). In addition, one of the features of the build-up of financial imbalances during boom periods that becomes problematic during any dramatic unwinding of these imbalances, identified by Minsky (1964) and Borio (2005), is a reduction in the ratio of liquidity to income. Requiring banks, therefore, to hold HQLAs sufficient to meet sustained net outflows under crisis conditions represents an attempt to maintain the ratio of liquidity to income and to engender ongoing confidence in financial institutions. To the degree that the Basel III liquidity measures perform these functions and provide a backstop to capital measures, they represent a positive change in the Australian context.

\section{Evaluation of Capital and Macroprudential Regulation Changes}

The changes to ADI capital regulation that lie at the core of the Basel III regime also represent positive and desirable developments in the Australian context. In particular, enhancing the quality of ADI capital to ensure that it provides a cushion of instruments genuinely available to absorb losses in the loan portfolio and related exposures, and ensuring that securitisation arrangements do not leave residual credit exposures unaccounted for in the provision of this protective cushion, can only enhance the safety of Australian deposit-takers. Whether they represent a fundamental change in philosophy compared to pre-GFC arrangements is less clear. Their importance is unquestionable but they are better characterised as significant refinements to the risk-based calculation of capital, identified as a result of the crisis, than as fundamental changes in regulatory philosophy. 
The status of Basel III's macroprudential apparatus is slightly more complicated. APRA has adopted the framework for implementing Basel III's CCCB but, along with the RBA, has expressed reservations about the conceptualisation of that framework, as highlighted earlier in the paper. That concern, it will be recalled, was that significant increases in the ratio of credit to GDP that signal the desirability of an increase in the $\mathrm{CCCB}$ under the Basel III regime, may occur for reasons other than the emergence of asset bubbles. The RBA and APRA (2012, p.19) also argue that the Basel III countercyclical capital buffer is not designed to lean against credit booms. This would be an ineffective policy, they suggest, because it only applies to the banking system, and nonbank lenders can continue funding demand for assets that fuels asset price inflation even if capital requirements are tightened. Aiyar, Calomiris \& Wieladek (2014) provide micro evidence from the UK to support this perspective. They report how tighter capital requirements led regulated banks to reduce lending while unregulated banks increased lending in response to the policy change.

Putting aside for the moment the issue of credit expansions having causes other than asset bubbles, it is not at all clear that the CCCB "does not purport to lean against credit booms". It is true that an important objective of the Basle Committee's CCCB is to ensure that additional capital is built up during credit booms in order to protect depositors against the realisation of greater risk associated with the unwinding of financial imbalances when the boom turns to bust. The following discussion from the Basel Committee's 2011 overview document for Basel III supports this perspective:

\footnotetext{
"As witnessed during the financial crisis, losses incurred in the banking sector during a downturn preceded by a period of excess credit growth can be extremely large. Such losses can destabilise the banking sector, which can bring about or exacerbate a downturn in the real economy. This in turn can further destabilise the banking sector. These interlinkages highlight the particular importance of the banking sector building up its capital defences in periods when credit has grown to excessive levels."
}

(BCBS 2011, p.7; italics added).

But, as argued earlier, it is always true that capital measures serve a dual purpose: they provide a cushion between loans and deposits, and they provide an incentive for bank managers to rethink their risk strategies due to the higher cost of funding riskier loans with capital as opposed to other sources. To the extent that the additional cost is passed on to borrowers in the form of higher loan rates, those borrowers must ensure that the uses to which funds are put are sufficiently profitable to justify the higher cost of funds when capital requirements are tightened. That this is an explicit part of the Basel Committee's 
rationale is indicated by the following comment which immediately follows that cited above:

The building up of these defences [those referred to in the quotation above] should have the additional benefit of helping to moderate excess credit growth.

(BCBS 2011, p.7; italics added).

The argument that Basel III's counter-cyclical capital buffer is not designed to lean against bubbles cannot, therefore, be sustained. The issue of leakage around such measures is a much more important one. However, even if such leakage does occur and macroprudential tools are not able to completely eliminate a particular instance of asset price inflation, what they are capable of is isolating the banking system from the financing of such inflation and limiting bank exposures to direct credit losses associated with the bursting of the resulting bubble (cf. Docherty 2008, p.101).

The argument put aside above that credit expansions may have causes other than their association with asset bubbles is certainly a possibility worthy of further investigation. Because of this possibility, the view of APRA and the RBA is that it may not be desirable to operate macroprudential regulation according to a rule which uses deviations of the credit to GDP ratio from trend. Instead, these regulators appear to advocate a more discretionary framework within which macroprudential regulation should be operated, one built around the supervisory approach of the PAIRS/SOARS system (RBA \& APRA 2012, p.14). This is not surprising given that APRA appears to have used an approach of this kind in 2003-2004 to deal with a set of credit dynamics similar in broad character to those that generated the global crisis:

The US sub-prime mortgage crisis and the substantial asset write-downs and losses of
many global financial institutions have sharpened market and regulatory attention on credit
quality in banks. This is not a new area of interest for APRA. Credit standards, particularly
in house lending, have been a major focus of APRA's research and on-site supervision of
ADIs for some years.

(APRA, 2008 Annual Report, p.12)

This statement seems to refer to the 2003-2004 episode which deserves closer attention. Prior to this period, the Australian cash rate had been cut in 2000 and 2001 from $6.25 \%$ to $4.25 \%$ following the bursting of the dot com bubble in the US, the slowing of the world economy in response to this event, and the slowing of the Australian construction sector around the time that the GST was introduced in mid-2000. The cycle of those cuts was completed in December 2001 with a 25 basis point reduction in the cash rate that left it at $4.25 \%$. Over the next two years (i.e. across 2002 and 2003), both housing credit and average dwelling prices in Australia grew well above their long run averages. Growth in 
housing credit for investors peaked at just in excess of 30\% p.a. in mid-2003 and for owner-occupiers averaged around 18\% p.a. across the whole 2002-2003 period (RBA, Financial Stability Review, March 2005, p.29). Inflation in house prices peaked over 20\% p.a. in the first half of 2002 and averaged around 18\% p.a. across the whole 2002-2003 period (RBA, Statement on Monetary Policy, November 2006, p.26). Inflation of apartment prices reached a slightly lower peak around the same time as the peak in house prices but fell away much more rapidly although it was still above $10 \%$ p.a. by the end of 2003. These rises continued an upward trend in average dwelling prices that had been occurring across the second half of the 1990s with previous peaks around 12\% p.a. in early 1998 and around 13\% in late 1999-early 2000 in the case of average house prices. But these previous peaks were well below those of the 2002-2003 period.

This strength in the Australian housing sector was one of the reasons that the RBA began raising the cash rate in May 2002 only five months after the most recent easing in December 2001. Other reasons included the fact that both the world and Australian economies had returned to stronger rates of growth than had been the case twelve months earlier with stronger household spending supported by wealth effects associated with the higher market value of houses. This spending was seen by the Reserve Bank as contributing to a potential worsening of the inflationary environment in the medium term. But the "expansionary policy setting" established by the interest rates cuts of 2000 and 2001 were separately viewed by the Reserve Bank as potentially fuelling "imbalances" associated with the increase in household indebtedness, the higher levels of house price inflation beginning to re-emerge in early 2002, and the potential for this combination to generate economic instability if it continued and further interest rate increases were required down the track. The Reserve Bank subsequently raised the cash rate by a further 25 basis points in June 2002, November 2003 and December 2003 each time citing houseprice dynamics as factors contributing to its decision.

The strong rises in house prices seen over recent years have also been associated with a rapid expansion in household debt, a process that carries longer-term risks if households become seriously over-extended.

(RBA, Monetary Policy Announcement, 8 May, 2002) ${ }^{16}$

Today's action is aimed at reducing the risk of potential imbalances, and thereby promoting sustainable expansion of the economy with low inflation.

(RBA, Monetary Policy Announcement, 5 June, 2002) ${ }^{17}$

\footnotetext{
${ }^{16}$ View at http://www.rba.gov.au/media-releases/2002/mr-02-10.html.

${ }^{17}$ View at http://www.rba.gov.au/media-releases/2002/mr-02-11.html.
} 
Credit outstanding is rising at around 14 per cent per year, and at over 20 per cent to households. That is a much faster rate of growth than can be expected to be consistent with economic stability over the longer run ... Given the above, the Board's view is that it is no longer prudent to continue with such an expansionary policy stance. The strength of demand for credit increases the danger associated with delaying a tightening of policy that is called for on general macroeconomic grounds.

(RBA, Monetary Policy Announcement, 5 November, 2003) ${ }^{18}$

... notwithstanding some early signs of a change in sentiment in the housing market, the overall prospects are for strong growth of the Australian economy ... Monetary policy is continuing to have a stimulatory effect on the economy through domestic credit expansion. .. The prevailing level of the cash rate after the November increase was still below neutral, and interest rates of financial intermediaries remained low by the standards of recent years.

(RBA, Monetary Policy Announcement, 3 December, 2003) $)^{19}$

There were no changes to the stance of monetary policy in 2004 and only a single 25 basis point tightening in 2005.

At the same time as the Reserve Bank was tightening monetary policy in 2003, APRA was focusing its supervisory attention on the same set of house price dynamics:

The year 2002/03 saw continued rapid growth in lending to the household sector, at an annual rate reaching around 20 per cent. The greater portion of this lending was for property and it spurred further strong rises in property prices.

(APRA, Annual Report, 2003, p.17)

The same link between credit growth and house price inflation is evident in this view of house price dynamics as in the RBA's analysis of these dynamics discussed above. APRA's policy response focused, however, on some aspects of ADI lending practices it saw as contributing to these high levels of credit growth. It reports asking ADIs to review their lending practices for housing in 2003, citing practices it regarded as "questionable" and warning ADIs that it was likely to require higher capital charges against such practices where they were discovered (APRA 2003b, p.17). Its 2004 Annual Report explicitly links these practices to "low doc" and "broker-facilitated" lending practices and it formally revised conditions for the concessional capital charge of 50\% against mortgage lending to ensure that such loans where characterised by an appropriate combination of verification of borrower loan-servicing ability, sufficiently low loan to valuation ratios, and coverage by mortgage insurance from October $2004 .^{20}$

\footnotetext{
${ }^{18}$ View at http://www.rba.gov.au/media-releases/2003/mr-03-15.html.

${ }^{19}$ View at http://www.rba.gov.au/media-releases/2003/mr-03-17.html.

20 The RBA's March 2005 Financial Stability Review later provided a more detailed discussion of lending practices which could be regarded as "questionable" from a financial safety perspective. These included greater use of mortgage brokers to originate loans, "low doc" loans which allowed a high degree of income and wealth self-verification designed to increase the access of self-employed persons to housing finance but which were open to potential abuse by other more risky borrowers, increases in debt-servicing burdens from
} 
The outcome of this combined focus of monetary policy, with the cash rate increasing by $1.00 \%$ in four steps between May 2002 and December 2003, and prudential regulation, with a tightening of conditions attached to concessional capital charges on house lending from October 2004, was that housing credit growth fell from above $20 \%$ at the end of 2003 to around $12 \%$ by the end of 2004 (RBA 2005, p.29), and house price inflation fell from around $20 \%$ at the end of 2003 to virtually zero by the end of 2004 (RBA 2006, p.26). In 2004, the proportion of housing loans in arrears and the proportion of nonperforming loans for on-balance sheet loans and securitised loans were both of the order of $0.2 \%$ (Lowe 2008, p.83). While these proportions rose during the Global Financial Crisis, they did not exceed about $0.6 \%$ whereas proportions in the U.S. were just above $2.0 \%$. It is not thus surprising that local authorities should have regarded prudential regulation as one of the contributing factors to the stability of the Australian financial system during the Global Financial Crisis. It appears that the kinds of underlying forces that shaped the crisis in the US, low interest rates, strong demand for real property, an accommodating financial system that was making increased use of financial innovation and reduced credit standards, were present in the Australian system to some degree in the period between 2001 and 2004, but that action by the RBA and APRA dampened the momentum of these forces and moderated the impact of asset price inflation before a bubble was able to form and burst.

This analysis suggests that macroprudential policy was not an innovation introduced after the GFC but was practiced within APRA's supervisory approach to prudential regulation before the crisis. While Basel III's CCCB provides an explicit new framework for the conduct of macroprudential regulation in Australia, the concept and conduct of macroprudential regulation was not a post-GFC innovation in this country. There is also evidence that macroprudential regulation has an even longer history in Australia although this perspective is little known. We give some consideration to this issue in the following section but it should be noted that the recognition of macroprudential supervision raises questions about the appropriate institutional structure for the conduct of both monetary policy and prudential regulation to which we will need to return.

the traditional $30 \%$ of gross income to much higher levels, and property valuation methods that depended less on careful internal as well as external inspection processes (RBA, 2005, pp.28-29). 


\section{Australian Macroprudential Regulation in Historical Perspective}

The explicit recognition of macroprudential regulation is an important development in Australia's post GFC prudential regulation framework even if the fundamental concept is not new. Given Australia's experience in the 1890s and 1980s with a pattern of intense competition in the banking sector, subsequently strong credit growth, asset price inflation, the sudden deflation of asset prices, losses at banks and deposit-taking institutions, and propagation of these financial disturbances to the real economy, new measures to address the accumulation of systemic risk associated with excessive credit growth are of considerable value. This conclusion is underscored by the observation that these factors also characterized the Global Financial Crisis (in the United States) as considered in Section 7 above.

It is important to note, however, that while the particular features of the Basel III macroprudential tools represented by countercyclical capital buffers are new, and APRA may well have been practicing a supervisory form of macroprudential regulation immediately prior to the crisis, the concept of macroprudential supervision has a much longer history in Australia. These new approaches simply make explicit a feature of the Australian system that has always been present although this fact has been poorly understood. Hogan \& Sharpe (1990), for example, argued that prudential regulation was really only introduced in Australia with the advent of the first Basel Accord in the mid1980s. Thomson \& Abbott (2000) argue that prior to this period prudential regulation was a mere side effect of Australia's monetary policy framework, and Lewis (1997) argues that this monetary policy framework was advocated by the 1937 Report of the Royal Commission into Australia's Monetary and Banking System and that this advocacy was the main contribution of that body. What these perspectives overlook, however, is that the monetary policy framework advocated by the 1937 Royal Commission was aimed at an essentially macroprudential objective. This objective explicitly drew a connection between the macroeconomic policy tools of liquidity management and interest rates, and the prudential issues of sound financial institution balance sheets and systemic stability.

This objective may be seen from the following excerpts from the final report of the Royal Commission:

During the period 1886 to 1890 , boom conditions prevailed in the eastern States of Australia, and in particular in Victoria. These were brought about principally by the lavish expenditure of the money borrowed from British lenders, either by the governments in the form of loans, or by private institutions such as land and finance companies, building societies, and some of the trading banks in the form of deposits.

(Commonwealth of Australia, 1937, p.94; emphasis added) 
It is possible that a strong central bank (had such then existed) might have been able to limit the unhealthy expansion that eventually brought about the crisis.

(Commonwealth of Australia, 1937, pp.100-01; emphasis added)

The general objective of an economic system is to achieve the best use of our productive resources both now and in the future. This means the fullest possible employment of people and resources under conditions that will provide the highest standard of living. It means, too, the reduction of fluctuations in general economic activity. . . In our opinion this result . . . will be most likely to follow from a system of central banking in which trading banks and other financial institutions are integral parts of the system, with a central bank which regulates the volume of credit and currency.

(Commonwealth of Australia Commission, 1937, p.201; emphasis added)

These excerpts indicate that the Royal Commission recommended improved monetary policy apparatus be put in place in the Australian financial system in order to prevent the kinds of banking collapses, and the real consequences flowing from these collapses, that occurred in Australia in 1893. The Commission viewed the boom conditions that preceded these collapses as having been fueled by excessive credit growth as the first excerpt above indicates. The second excerpt indicates the Commission's belief that a central bank would be able to curtail such an expansion. The third excerpt then specifies how this result could be achieved: by regulating the volume of credit.

One of the key recommendations of the Commission was, consequently, that the Commonwealth Bank should have the power, with the consent of the Federal Treasurer, to require Australian banks to deposit with it some specified proportion of its deposit liabilities for a period of between six and eighteen months (see Recommendations (9) to (11); Commonwealth of Australia, 1937, pp.228-9). The limited duration of this power indicates that it was originally envisaged as one to be exercised only periodically. That is, it was a measure to be used by the central bank only when boom conditions were developing and its objective was to limit the availability of credit in those conditions with a view to preventing or reducing the boom, avoiding the subsequent downturn and the effects this could have on the real economy in terms of higher unemployment and lost output. In short, these powers were viewed by the Royal Commission as macroprudential measures.

Implementation of these measures was prevented by the outbreak of World War II and delayed until passage of the 1945 Banking Act which, as suggested in Section 4 above, was largely based on the analysis of the Royal Commission (Bell 2004, p.11) with one important alteration. The proposed deposits that banks would be required to keep at the Commonwealth Bank were instituted on a permanent basis rather than a periodic one, and this enabled the Bank to exert a continuous influence over liquidity conditions within the 
Australian financial system rather than simply being able to act during a boom. This broadening of the Commonwealth Bank's sphere of influence thus facilitated the operation of day to day monetary policy in addition to the underlying set of tools designed to restrain booms and busts. It was thus not the case that the principal contribution of the 1937 Royal Commission was the establishment of a monetary policy framework as we

understand it, nor that prudential policy was the by-product of this monetary policy apparatus. It was in fact the opposite: the monetary policy framework was established as the by-product of an essentially macroprudential apparatus designed to restrain booms, asset price inflation, and the subsequent real effects of banking collapses.

The reverse impression observed in the literature results from the fact that monetary policy can be used more frequently than macroprudential policy since minor fluctuations in liquidity conditions that affect the real economy occur more frequently than do significant boom conditions. This attracted greater attention over the years to the monetary policy dimensions of the Commonwealth Bank's, and later the Reserve Bank's powers, thus creating the impression of their greater significance. But it was always the case that the Australian central bank's ability to influence credit conditions was envisaged as having a macroprudential objective. Whether this instrument constitutes the best possible macroprudential instrument, and whether the countercyclical capital buffer of the Basel III regime is a superior macroprudential instrument are separate questions. But this analysis furnishes the perspective that adoption of countercyclical capital buffers in Australia as a result of implementing Basel III or APRA's apparent supervisory version of macroprudential regulation do not so much constitute the introduction of macroprudential regulatory possibilities as they make the macroprudential dimension of existing monetary and banking policy more explicit.

\section{Appropriate Monetary Policy/Prudential Regulation Institutional Structure}

Such explicit recognition of the possibility and importance of macroprudential policy raises some important questions about the appropriate institutional structure for the conduct of monetary policy and prudential regulation. As discussed earlier, monetary policy and prudential regulation functions were separated in 1996 in Australia in accordance with the recommendations of the Wallis Committee. The RBA was given responsibility for the conduct of monetary policy and stability of the financial system whereas APRA was given responsibility for prudential regulation conceived in terms of 
micro-prudential supervision. ${ }^{21}$ The nature of macroprudential regulation, however, brings this separation into question.

As discussed in Section 5, the Wallis Report argued for the separation of the RBA from the prudential regulator on the grounds that a single institution responsible for both monetary policy and the regulation of individual institutions would face a conflict of interest (Financial System Inquiry, 1997, p.214). This conflict, the inquiry suggested, would affect the operation of monetary policy because a central bank with responsibility for the health of individual financial institutions might be tempted not to raise interest rates in particular kinds of inflationary circumstances. For example, where a sufficiently high proportion of bank borrowers were sufficiently highly leveraged, an increase in interest rates may well raise the ratio of interest payments to income, so that interest payments absorbed a large proportion of cash flows. In such circumstances, loan defaults would rise and given that a large proportion of borrowers would be affected, this could put banks under the threat of losses large enough to render them insolvent. This would reflect negatively on the central bank/prudential regulator's reputation, and it would thus have an incentive to tolerate higher inflation on average rather than to raise interest rates in order to bring inflation under control. This conflict of interest would be removed where a central bank faced the single objective of fighting inflation.

This argument works, however, as effectively to support the case for a dual objective as it does to support the case against one. This is so because the argument is premised on the existence of an interaction between monetary policy and prudential regulation, and this interaction ultimately makes a dual objective desirable. Where a single institution is responsible for both monetary policy and prudential regulation, that institution knows that failure to achieve either its inflation mandate or its mandate for financial stability will reflect negatively upon its reputation. However, the additional powers associated with the prudential regulation function enables the institution to have in place guidelines that prevent the build-up of excessive bank exposure to highly leverage borrowers, and this strengthens the institution's confidence that tighter monetary policy will not threaten the viability of banks. Knowledge of conditions and the power to influence these conditions under one aspect of its dual mandate thus informs and strengthens the execution of responsibilities under the other aspect of this mandate.

\footnotetext{
${ }^{21}$ Although APRA was later given some explicit responsibility for the promotion of financial stability.
} 
This argument is highlighted by the stress placed on inter-agency co-ordination by the RBA \& APRA (2012) as a key dimension of the Australian framework for the management of systemic stability. This is partly achieved through the Council of Financial Regulators (CFR) and partly through direct links between the two institutions. But whereas such co-operation is dependent upon the maintenance of goodwill and cordial inter-agency relations (which may deteriorate given the right combination of political factors), the structuring of a dual mandate on a single institution necessitates the effective co-ordination of these responsibilities. There is thus an argument for reconsidering the separation of the RBA and APRA implemented in 1998 because of the close link between monetary policy and prudential regulation highlighted by the nature of macroprudential regulation.

\section{Conclusion}

This paper has reviewed the nature of Australian bank prudential regulation before and after the Global Financial Crisis. It began by providing a detailed conceptual framework for understanding the functions of banks and deposit-takers, the theory of what can go wrong with the operation of these institutions, and the logic of prudential regulation. It then examined the transition from what Hogan \& Sharpe called Australia's informal system of prudential regulation to the formal capital-based system that was implemented in the 1980s, and to the separation of central banking from prudential supervision recommended by the Wallis Committee in 1997 and implemented by the Howard Government in 1998 with the creation of the Australian Prudential Regulation Authority (APRA). APRA's implementation of the Basel II revisions to prudential regulation and its PAIRS/SOARS supervisory framework for prudential regulation of Australian deposittakers in the years before the crisis were also outlined.

All of this provided important background to the state of prudential regulation in Australia when the Global Financial Crisis hit in 2007. The nature of the crisis was then given careful attention as was its implications for international revisions to prudential regulatory standards in the form of Basel 2.5 and Basel III before the major changes to Australia's system of prudential regulation after the Global Financial Crisis were outlined. In summary these involved clarification of the nature of the government safety net, strengthening of pre-GFC capital requirements for ADIs, the introduction of a new capitalbased apparatus for engaging in macroprudential regulation, and a substantial 
strengthening of liquidity regulation. An evaluation of these changes and the degree to which they made fundamental differences to pre-GFC regulation was finally offered.

The paper's major conclusions were that the introduction of the Financial Claims Scheme was clear a change to pre-GFC arrangements and one to be welcomed. In some respects, however, it constituted a clarification and formalisation of an existing perception within the Australian community suggested by the depositor protection provisions of the Banking Act rather than a fundamental change to arrangements for protecting bank depositors. The introduction of the new Basel III liquidity regime, it was concluded, represents a more fundamental modification. Requiring banks to hold enough liquidity to manage net cash outflows over a thirty day period in stressed conditions, engenders confidence in deposit-takers and provides a backstop to the effectiveness of capital measures designed to reduce the likelihood of financial instability.

The changes to ADI capital regulation that lie at the core of the Basel III regime also represent positive and desirable developments in the Australian context. In particular, enhancing the quality of ADI capital to ensure that it provides a cushion of instruments genuinely available to absorb losses in the loan portfolio and related exposures, and ensuring that securitisation arrangements do not leave residual credit exposures unaccounted for in the provision of this protective cushion, can only enhance the safety of Australian deposit-takers. Whether they represent a fundamental change in philosophy compared to pre-GFC arrangements is less clear. Their importance is unquestionable but the paper concludes that they are better characterised as important refinements to the riskbased calculation of capital than as fundamental changes to regulatory philosophy.

The status of Basel III's macroprudential apparatus is slightly more complicated. This apparatus appears on the surface to be an innovation in the Australian and international systems of prudential regulation. But the paper argues that APRA had been engaging in a modified form of such regulation before the GFC and that there is a longer tradition of thinking about such regulation in Australia dating back to the Napier Royal Commission of 1935-37. While it is argued that the new apparatus is to be welcomed, macroprudential policy is not a post-GFC innovation.

The paper lastly argues that the importance of financial stability as a policy objective and the nature of macroprudential regulation which has the potential to address this objective, raise questions about the wisdom of having split monetary policy and prudential regulation functions in 1998. It is, therefore, argued that the question of the best institutional structure within which to allocate these functions should be revisited. 


\section{References}

Aiyar S., Calomiris C.W. and Wieladek T. (2014), "Does Macro-Prudential Regulation Leak? Evidence from a UK Policy Experiment", Journal of Money, Credit and Banking, 46 (1), pp.181-214.

Akerlof G. (1970), “The Market for Lemons: Quality Uncertainty and the Market Mechanism", Quarterly Journal of Economics, 84, pp.488-500.

Allen F. and Santomero A.M. (1997), "The Theory of Financial Intermediation", Journal of Banking \& Finance, 21, pp.1461-1485.

Allen F. and Santomero A.M. (2001), "What Do Financial Intermediaries Do?", Journal of Banking \& Finance, 25, pp.271-294.

Australian Financial System Inquiry (1981), Final Report, Canberra: Australian Government Printing Service.

Australian Prudential Regulation Authority (2003a), "Introducing PAIRS: APRA's Probability and Risk Rating System", APRA Insight, $1^{\text {st }}$ quarter, pp.4-5.

Australian Prudential Regulation Authority (2003b), Annual Report, Canberra: Commonwealth of Australia.

Australian Prudential Regulation Authority (2004), Annual Report, Canberra: Commonwealth of Australia.

Australian Prudential Regulation Authority (2008), Annual Report, Canberra: Commonwealth of Australia.

Australian Prudential Regulation Authority (2009), Annual Report, Canberra: Commonwealth of Australia.

Australian Prudential Regulation Authority (2010), Annual Report, Canberra: Commonwealth of Australia.

Australian Prudential Regulation Authority (2011), Discussion Paper: Implementing Basel III Capital Reforms in Australia, September, Sydney.

Australian Prudential Regulation Authority (2014), Prudential Standard APS 210 Liquidity, November, Sydney.

Bajada C. and Trayler R. (2010), "How Australia Survived the Global Financial Crisis", in Gup B. (ed.), The Financial and Economic Crises: An International Perspective, Edward Elgar: Cheltenham, UK and Northampton, USA, pp.139-154.

Basel Committee on Banking Supervision (2006), International Convergence of Capital Measurement and Capital Standards: A Revised Framework, June, Basel: Bank for International Settlements.

Basel Committee on Banking Supervision (2009), Enhancements to the Basel II Framework, July, Basel: Bank for International Settlements.

Basel Committee on Banking Supervision (2010a), The Basel Committee's Response to the Financial Crisis: Report to the G20, October, Basel: Bank for International Settlements.

Basel Committee on Banking Supervision (2010b), An Assessment of the Long-term Economic Impact of Stronger Capital and Liquidity Requirements, August, Basel: Bank for International Settlements.

Basel Committee on Banking Supervision (2011), Basel III: A Global Regulatory Framework for More Resilient Banks and Banking Systems, June, Basel: Bank for International Settlements.

Basel Committee on Banking Supervision (2013), Basel III: The Liquidity Coverage Ratio and Liquidity Risk Monitoring Tools, January, Basel: Bank for International Settlements.

Bell S. (2004), Australia's Money Mandarins: The Reserve Bank and the Politics of Money, Cambridge: Cambridge University Press.

Berger A.N. and Udell G.F (1995), "Some Evidence on the Empirical Significance of Credit Rationing", Journal of Political Economy, 100, pp.1047-1077. 
Bernanke B. (1983), "Non-monetary Effects of the Financial Crisis in the Propagation of the Great Depression", American Economic Review, 73, pp.257-76.

Bernanke B. and Lown C. (1991), "The Credit Crunch", Brooking Papers on Economic Activity, 2, pp.205-39.

Bhattacharya S., Boot A.W.A. and Thakor A.V. (1998), "The Economics of Bank Regulation", Journal of Money Credit and Banking, 30 (4), pp.745-770.

Bhattacharya S. and Thakor A.V. (1993), "Contemporary Banking Theory", Journal of Financial Intermediation, 3, pp.2-50.

Boehm E.A. (1971), Prosperity and Depression in Australia 1887-1897, Oxford: The Clarendon Press.

Borio C. (2005), "Monetary and Financial Stability: So Close and Yet So Far", National Institute Economic Review, 192, pp.84-101.

Brunnermeier M.K. (2009), "Deciphering the Liquidity and Credit Crunch 2007-2008", Journal of Economic Perspectives, 23 (1), pp.77-100.

Bryant J. (1980), “A Model of Reserves, Bank Runs and Deposit Insurance”, Journal of Banking \& Finance, 4, pp.335-44.

Calomiris C. (2011), "Origins of the Sub-prime Crisis", in Demirguc-Kunt A., Evanoff D.D. and Kaufman G.G. (eds.), The International Financial Crisis: Have the Rules of Finance Changed?, Singapore: World Scientific, pp.73-91.

Chant J. (1992), "The New Theory of Financial Intermediation” in Dowd K. \& Lewis M.K. (eds.), Current Issues in Financial and Monetary Economics, London: Macmillan, pp.42-65.

Cohen B. and Remolona E. (2008), "The Unfolding Turmoil of 2007-2008: Lessons and Responses", in Bloxham P. \& Kent C. (eds.), Lessons from the Financial Turmoil of 2007 and 2008, Sydney: Reserve Bank of Australia, pp.7-22.

Commonwealth of Australia (1937), Report of the Royal Commission Appointed to Inquire into the Monetary and Banking Systems at Present in Operation in Australia, Canberra: L.F. Johnston, Commonwealth Government Printer.

Crotty J. (2009), "Structural Causes of the Global Financial Crisis: A Critical Assessment of the 'New Financial Architecture' ", Cambridge Journal of Economics, 33, pp.563-580.

Dale R. (1996), "Regulating the New Financial Markets", in Edey M. (ed.), The Future of the Financial System, Sydney: Reserve Bank of Australia, pp.215-245.

Davis K. (2011), "The Australian Financial System in the 2000s: Dodging the Bullet", in Gerard H. \& Kearns J. (eds.), The Australian Economy in the 2000s, Sydney: Reserve Bank of Australia, pp.301-348.

Diamond D. (1984), "Financial Intermediation and Delegated Monitoring", Review of Economic Studies, 51 (3), pp.393-414.

Diamond D. \& Dybvig P. (1983), "Bank Runs, Deposit Insurance and Liquidity”, Journal of Political Economy, 91, pp.401-19.

Docherty P. (2005), Money and Employment: A Study of the Theoretical Implications of Endogenous Money, Cheltenham: Edward Elgar.

Docherty P. (2008), "Basel II and the Political Economy of Banking Regulation-Monetary Policy Interaction", International Journal of Political Economy, 37, (2), pp.82-106.

Docherty P. (2010), "Credit Evaluation, Capital Adequacy and Asset Price Inflation: Key Issues for Prudential Regulation after the Global Financial Crisis", International Journal of Applied Economics and Econometrics, 18, (3), pp.29-57.

Docherty P., Terry C. and Trayler R. (2005), "The Impact of the Basel II Capital Accord on Australian Banks", in Gup B. (ed.), The New Basel Capital Accord, New York: Lexington Books, pp.305-336.

Dow S. (1996), "Why the Banking System Should be Regulated", Economic Journal, 106, May, pp.698-707. 
Dowd K. (1996), “The Case for Financial Laissez-Faire”, Economic Journal, 106, May, pp.697687.

Dymski G.A. (2010), "Why the Subprime Crisis is Different: A Minskyian Approach", Cambridge Journal of Economics, 34, pp.239-255.

Edey M. and Gray B. (1996), "The Evolving Nature of the Financial System”, in Edey M. (ed.), The Future of the Financial System, Sydney: Reserve Bank of Australia, pp.6-44.

Edey M. (2008), "The Economy in Late 2008: Conditions and Prospects", Reserve Bank of Australia Bulletin, December, pp.19-26.

Edwards P. (1999), "Managing Risk and Capital in Financial Conglomerates", in Matten C. (ed.), Risk and Capital Management: Proceedings of a Conference, Sydney: Australian Prudential Regulation Authority, pp.108-123.

Ellis L. (2009), "The Global Financial Crisis: Causes, Consequences and Countermeasures", Reserve Bank of Australia Bulletin, May, pp.24-34.

Fama E. (1985), “What's Different About Banks?”, Journal of Monetary Economics, 15, pp.29-39.

Financial System Inquiry (1997), Final Report, Canberra: Australian Government Printing Service.

Financial System Inquiry (2014), Final Report, Canberra: Commonwealth Government Treasury.

Fraser B. W. (1990), “Aspects of the Reserve Bank's Supervisory Function” Bulletin, RBA, May, pp.10-17.

Galati G. and Moessner R. (2013), "Macroprudential Policy - A Literature Review", Journal of Economic Surveys, 27 (5), pp.846-878.

Grenville S. (1991), "The Evolution of Financial Deregulation", in Mcfarlane I. (ed.), The Deregulation of Financial Intermediaries, Sydney: Reserve Bank of Australia, pp.3-35.

Gizycki M. and Lowe P. (2000), "The Australian Financial System in the 1990s", Gruen D. \& Srestha S. (eds.), The Australian Economy in the 1990s, Sydney: Reserve Bank of Australia, pp.180-215.

Goodhart C.A.E. (1988), The Evolution of Central Banks, Cambridge MA: MIT Press.

Gorton G. (1988), Banking Panics and Business Cycles", Oxford Economic Papers, 40, pp.751-81.

Haldane A. (2012), "In Favour of Macro-prudential Regulation", Risk, September, pp.78-80.

Hanson S.G., Kashyap A.K. and Stein J.C. (2011), “A Macroprudential Approach to Financial Regulation", Journal of Economic Perspectives, 25 (1), pp.3-28.

Harper I. R. (1997), “The Wallis Report: An Overview”, Australian Economic Review, 30 (3), pp.288-300.

Henckel T. (2010), “Australia Lifts its Bank Guarantees”, East Asia Forum, 11th March. View online at http://www.eastasiaforum.org.

Hogan W. P. (1982), "Financial Exegesis: Reviewing the Australian Financial System," Economic Papers, 1 (1), pp.49-64.

Hogan W.P. (1997), “Wallis Report: Strategy to What Purpose?", Accounting \& Performance, 3 (3), pp.27-41.

Hogan W.P. (1999), "The Future of Banking: A Survey", Economic Record, 75, December, pp.417-427.

Hogan W. P. and Sharpe I. G. (1983), "On Prudential Controls", Economic Papers, Special Edition, April, pp.144-74.

Hogan W. and Sharpe I.G. (1990), "Prudential Regulation of Australian Banks", Economic Record, 66, pp.127-45.

Hogan W. and Sharpe I.G. (1997a), "Prudential Regulation of the Financial System: A Functional Approach", Agenda, 4, pp.15-28. 
Hogan W. and Sharpe I. G. (1997b), "Financial System Reform: Regulatory Structure, Financial Safety, Systemic Stability and Competition Policy," The Economic and Labour Relations Review, pp.318-332.

Hunt B. and Terry C. (2005), Financial Institutions and Markets, 4th edition, South Melbourne: Nelson.

James C. (1991), "The Losses Realised in Bank Failures”, Journal of Finance, 46, pp.1223-1242.

Jensen M. and Meckling W.H. (1976), "Theory of the Firm, Managerial Behaviour, Agency Costs, and Ownership Structure", Journal of Financial Economics, 2 (4), pp.205-360.

Kindleberger, C.P. (2000), Manias, Panics, and Crashes: A History of Financial Crises, Fourth edition, New York: John Wiley \& Sons.

Kregel J. (2008), “Using Minsky's Cushion of Safety to Analyse the Crisis in the U.S. Subprime Mortgage Market', International Journal of Political Economy, 37 (1), pp.2-23.

Lavoie M. (1999), "The Credit-led Supply of Deposits and the Demand for Money: Kaldor's Reflux Mechanism as Previously Endorsed by Joan Robinson", Cambridge Journal of Economics, 23, pp.103-113.

Leland H. E. and Pyle D. (1977), "Informational Asymmetries, Financial Structure and Financial Intermediation", Journal of Finance, 32, pp.371-387.

Lewis M.K. (1997), "The Wallis Inquiry: Its Place in the Evolution of the Australian Financial System", Accounting Forum, 21 (2), pp.229-253.

Lowe P. (2008), "The Financial Cycle and Recent Developments in the Australian Financial System", Reserve Bank of Australia Bulletin, August, pp.80-89.

Lummer S.L. and McConnell J.J. (1989), "Further Evidence on the Banking Lending Process and the Capital Market Response to Bank Loan Agreements", Journal of Financial Economics, 25, pp.99-122.

Merrett D.T. (2013), "The Australian Bank Crashes of the 1890s Revisited", Business History Review, 87, pp.407-429.

Merton R. C. (1995) "Financial Innovation and the Management and Regulation of Financial Institutions", Journal of Banking \& Finance, 19 (3-4), pp. 461-481.

Milbourne R. (1990), "Money and Finance", in Grenville S. (ed.), The Australian Macro-Economy in the 1980s, Sydney: Reserve Bank of Australia.

Minsky H.P. (1964), "Longer Waves in Financial Markets: Financial Factors in the More Severe Depressions", American Economic Review, 54 (3), pp.324-335.

Mishkin F.S. (2001), "Prudential Supervision: Why Is It Important and What Are the Issues?", in Mishkin F.S. (ed.), Prudential Supervision: What Works and What Doesn't, Chicago: Chicago University Press, pp.1-29.

Mishkin F.S. (2013), The Economics of Money, Banking, and Financial Markets, 10th edition, Boston: Pearson.

O'Brien K.P. (1993), “The Thrift Institutions: Building Societies, Credit Unions and Friendly Societies", in Lewis M.K. and Wallace R.H. (eds.), The Australian Financial System, Melbourne: Longman Cheshire, pp.83-135.

Peterson M.A. and Rajan R.G. (1994), “The Benefits of Firm-Creditor Relationships: Evidence from Small Business Data", Journal of Finance, 49 (1), pp.3-37.

Reserve Bank of Australia (1985), Prudential Supervision of Banks, Prudential Statement No. A1, Sydney.

Reserve Bank of Australia (1988), Capital Adequacy of Banks, Prudential Statement No. C1, Sydney.

Reserve Bank of Australia (1989), 'Campbell Committee Revisited - Prudential Supervision", Reserve Bank of Australia Bulletin, July, pp.20-27. 
Reserve Bank of Australia (1991), "Directions for Prudential Supervision in the 1990s", Reserve Bank of Australia Bulletin, May, pp.6-13.

Reserve Bank of Australia (2007), Financial Stability Review, September, Sydney.

Reserve Bank of Australia (2008a), Financial Stability Review, March, Sydney.

Reserve Bank of Australia (2008b), Financial Stability Review, September, Sydney.

Reserve Bank of Australia (2009a), Financial Stability Review, March, Sydney.

Reserve Bank of Australia (2009b), Financial Stability Review, September, Sydney.

Reserve Bank of Australia (2010), Financial Stability Review, March, Sydney.

Reserve Bank of Australia and Australian Prudential Regulation Authority (2012), Macroprudential Analysis and Policy in the Australian Financial Stability Framework, September, Sydney.

Schwartz C. (2010), "The Australian Government Guarantee Scheme", Reserve Bank of Australia Bulletin, March, pp.19-26.

Skreta V. and Veldkamp L. (2009), "Ratings Shopping and Asset Complexity: A Theory of Ratings Inflation", Journal of Monetary Economics, 56, pp. 678-695.

Stevens, G. (2008), "Recent Financial Developments", Reserve Bank of Australia Bulletin, April, pp.20-25.

Stockhammer E. (2011), "Neoliberalism, Income Distribution and the Causes of the Crisis", in Arestis P., Sobreira R. and Oreiro J.L. (eds.), The Financial Crisis: Origins and Implications, London: Palgrave Macmillan, pp.234-258.

Taylor J.B. (2009), Getting Off Track: How Government Actions and Interventions Caused, Prolonged and Worsened the Financial Crisis, Stanford: Hoover Institution Press.

Terry C. (2009), "The New Basel Capital Accord: A Major Advance at a Turbulent Time", Agenda, 16 (1), pp.25-43.

Thomson D. and Abbott M. (2000), "Australian Financial Prudential Supervision: An Historical View”, Australian Journal of Public Administration, 59 (2), pp.75-88.

Thompson G. J. (1991a), "Directions for Prudential Supervision in the 1990s," Reserve Bank of Australia Bulletin, May, pp.6-13.

Thompson G. (1991b), "Prudential Supervision", in Mcfarlane I. (ed.), The Deregulation of Financial Intermediaries, Sydney: Reserve Bank of Australia, pp.115-142.

Turner G. (2011), "Depositor Protection in Australia”, Reserve Bank of Australia Bulletin, December, pp.45-55.

Valentine T. J. (1983), "Campbell and the Critics", Economic Papers, Special Edition, April, pp.206-21.

Wray L.W. (2009), “The Rise and Fall of Money Manager Capitalism: A Minskian Approach", Cambridge Journal of Economics, 33, pp.807-828. 